Carlos Henrique Pereira Alcântara

\title{
A Teoria da Adequação Social no Direito Penal: ASPECTOS CONTROVERTIDOS E APLICAÇÃo NA JURISPRUDÊNCIA DO Tribunal de Justiça de São Paulo
}

\author{
DisserTaÇão DE MESTRAdO \\ Orientadora: Professora Associada Mariângela Gama de MagalHães \\ GOMES
}

UNiVERSidAde de SÃo PAUlo

Faculdade de Direito

SÃo PAUlo - SP 


\section{Carlos Henrique Pereira Alcântara}

A Teoria da Adequação Social no Direito Penal: ASPECTOS CONTROVERTIDOS E APLICAÇÃo NA JURISPRUDÊNCIA DO Tribunal de Justiça de São Paulo

Dissertação apresentada à Banca Examinadora do Programa de Pós-Graduação em Direito, da Faculdade de Direito da Universidade de São Paulo, como exigência parcial para obtenção do título de Mestre em Direito, na área de Direito Penal, sob a orientação da Professora Associada Dra. Mariângela Gama de Magalhães Gomes.

Universidade de São Paulo

FACUldade de Direito

SÃo PAULO - SP 
Catalogaçăo da Publicaçăo

Serviço de Biblioteca e Documentação

Faculdade de Direito da Universidade de São Paulo

Alcântara, Carlos Henrique Pereira

A teoria da adequaçăo social no direito penal: aspectos

controvertidos e aplicação na jurisprudência do Tribunal de Justiça de

São Paulo / Carlos Henrique Pereira Alcântara ; orientadora Mariângela Gama de Magalhães Gomes -- São Paulo, 2017.

229

Dissertação (Mestrado - Programa de Pós-Graduação em Direito Penal, Medicina Forense e Criminologia) - Faculdade de Direito, Universidade de São Paulo, 2017.

1. Direito Penal. 2. Adequaçăo social. 3. Teoria do delito. 4. Hermenêutica jurídica. 5. Jurisprudência. I. Gomes, Mariângela Gama de Magalhães, orient. II. Título. 
ALCÂNTARA, Carlos Henrique Pereira.

A teoria da adequação social no Direito Penal: aspectos controvertidos e aplicação na jurisprudência do Tribunal de Justiça de São Paulo.

Dissertação apresentada à Faculdade de Direito da Universidade de São Paulo como exigência parcial para obtenção do título de Mestre em Direito.

Aprovado em:

Banca Examinadora

Prof.Dr. Instituição:

Julgamento: Assinatura:

Prof.Dr. Instituição:

Julgamento: Assinatura:

Prof.Dr Instituição:

Julgamento: Assinatura:

Prof.Dr Instituição:

Julgamento: Assinatura: 
Ao meu pai, José Carlos 


\section{AGRADECIMENTOS}

Agradeço, primeiramente, a Deus, por possibilitar a realização de mais um sonho.

Agradeço à minha mãe, que forneceu todas as bases materiais e imateriais para o alcance dos meus objetivos. Nunca conseguirei retribuir todo o apoio, dedicação, incentivo, carinho e suporte prestados durante essa trajetória.

Agradeço também à minha irmã e a todos os meus familiares, sem os quais não teria chegado até aqui.

Direciono os meus agradecimentos especiais a Daiana Santos Ryu, peça fundamental em todos os momentos da minha vida. Seu companheirismo e sua ajuda foram essenciais para a concretização e conclusão deste estudo. Muito obrigado por estar sempre ao meu lado. Espero algum dia retribuir à altura.

Agradeço imensamente à professora Mariângela Gama de Magalhães Gomes, pelo voto de confiança em mim depositado e por acreditar que, de alguma forma, este trabalho poderia contribuir para a construção de um Direito Penal mais lógico e racional. Não tenho palavras para expressar o quanto sou grato pela revisão atenta desta dissertação e pela liberdade que me concedeu durante todo o desenvolvimento da pesquisa.

Também não poderia deixar de agradecer as valiosas contribuições prestadas pelos professores Renato de Mello Jorge Silveira e Alamiro Velludo Salvador Netto na banca de qualificação. Suas críticas e sugestões serviram de base para o aprimoramento deste trabalho.

Agradeço, ainda, à professora Elane Vasconcelos de Campos Flor, cujos preciosos ensinamentos me motivam a dar prosseguimento aos estudos.

Aos meus colegas da pós-graduação, José Paulo Micheletto Naves e Bruna Rachel de Paula Diniz, os meus mais sinceros agradecimentos pelas dúvidas, angústias e anseios compartilhados durante todo o Mestrado.

Aos meus grandes amigos, em especial a Ricardo Ferreira da Silva, pelo enorme incentivo nessa fase.

Não poderia deixar de agradecer também à Dra. Patrícia Helena Feitosa Milani e ao Dr. Matheus Amstalden Valarini, por terem sido tão compreensivos nas vezes em que tive que me ausentar do trabalho.

Aos alunos da Faculdade de Direito do Largo de São Francisco, muito obrigado pela rica troca de experiências durante as monitorias. 
À biblioteca da Faculdade de Direito da USP e ao Instituto Brasileiro de Ciências Criminais, por oferecerem grande parte da bibliografia que serviu de base para a construção deste trabalho.

Agradeço, por fim, ao Tribunal de Justiça de São Paulo, pela disponibilização dos acórdãos de forma tão acessível e prática, viabilizando a realização deste estudo.

A todos, os mais sinceros agradecimentos. 
"Sans la culture, et la liberté relative qu'elle suppose, la societé, même parfaite, n'est qu'une jungle. C'est pourquoi toute création authentique est un don à l'avenir" 


\section{RESUMO}

ALCÂNTARA, Carlos Henrique Pereira. A teoria da adequação social no direito penal: aspectos controvertidos e aplicação na jurisprudência do Tribunal de Justiça de São Paulo. Dissertação (Mestrado). Faculdade de Direito, Universidade de São Paulo, São Paulo, 2017.

A evolução do tratamento dado à teoria da adequação social no Direito Penal sinaliza tratar-se de um instituto jurídico relevante, porém alvo de muitas objeções. O presente estudo tem como propósito inicial a investigação dos aspectos controvertidos que permeiam a teoria, a fim de que se possa traçar um panorama geral da função por ela desempenhada no cenário jurídico-penal. Para tanto, serão levadas em consideração as principais discussões doutrinárias sobre o conceito, a importância, as diferenças em relação a outros institutos e a inserção na teoria do delito. Com um arcabouço teórico formado, será possível analisar criticamente o modo como a jurisprudência do Tribunal de Justiça de São Paulo vem apreciando a adequação social. Para isso, serão empregados os métodos quantitativo e qualitativo para a exposição de algumas decisões recentes que tangenciam os fundamentos da teoria na aplicação do direito. À luz das construções doutrinárias, será possível traçar um panorama geral dos principais erros do magistrado na análise dessa ferramenta jurídica. Por fim, mostra-se importante o estabelecimento de alguns critérios e parâmetros para a aplicação da teoria da adequação social na seara penal. O propósito desse trabalho é contribuir para a construção de um Direito Penal em consonância com a realidade social.

Palavras-chave: Direito Penal. Adequação social. Teoria do delito. Hermenêutica jurídica. Jurisprudência. 


\section{RÉSUMÉ}

ALCÂNTARA, Carlos Henrique Pereira. La théorie de l'adéquation sociale en droit pénal: des aspects controversés et l'application dans la jurisprudence de la Cour de Justice de São Paulo. Mémoire (Maîtrise). Faculté de Droit, Université de São Paulo, São Paulo, 2017.

L'évolution du traitement donné à la théorie de l'adéquation sociale en droit pénal indique qu'elle constitue un institut juridique important, mais elle est l'objet de beaucoup d'objections. Le présent mémoire a pour objectif initial l'étude des principaux aspects controversés qui imprègnent la théorie, afin de donner un aperçu genéral de sa fonction dans le scénario juridique-pénal. Ainsi, il faudra pendre en compte les discussions doctrinales sur le concept, l'importance, les différences par rapport aux autres instituts et l'insertion dans la théorie du crime. Avec un cadre théorique formé, il sera possible d'analyser critiquement la manière dont la jurisprudence de la Cour de Justice de São Paulo est favorable à apprécier l'adéquation sociale. Pour cela, les méthodes quantitatives et qualitatives seront utilisées pour exposer quelques décisions récentes qui touchent les fondements de la théorie dans l'application de la loi. A la lumière de la construction doctrinale, un aperçu général des principales erreurs du magistrat sera dressé dans l'analyse de cet outil juridique. Enfin, c'est important d'établir certains critères et paramètres pour l'application de la théorie de l'adéquation sociale en champ pénal. Le but de ce mémoire est de contribuer à la construction d'un Droit Penal conforme à la réalité sociale.

Mots-clés: Droit pénal. Adéquation sociale. Théorie du crime. Herméneutique juridique. Jurisprudence. 


\begin{abstract}
ALCÂNTARA, Carlos Henrique Pereira. The theory of social adequacy in criminal law: controversial aspects and application in the jurisprudence of the Court of Justice of São Paulo. Dissertation (Master). Law School, University of São Paulo, São Paulo, 2017.

The evolution of the treatment given to the theory of social adequacy in Criminal Law indicates that it is a relevant legal institute, but it is the object of much criticism. The present research has the initial purpose of investigating the controversial aspects that permeate the theory, in order to provide an overview of the role played by it in the legalpenal scenario. In order to do so, the main doctrinal discussions on the concept, importance, differences in relation to other institutes and insertion in the theory of crime will be taken into account. With a theoretical framework formed, it will be possible to critically analyze the way in which the jurisprudence of the Court of Justice of São Paulo has been appreciating the social adequacy. For this, the quantitative and qualitative methods will be used for the exposition of some recent decisions that analyze the bases of the theory in the application of the law. In the light of doctrinal constructions, it will be possible to give an overview of the main errors of the magistrate in the analysis of this legal tool. Finally, it is important to establish some criteria and parameters for the application of the theory of social adequacy in criminal justice. The purpose of this paper is to contribute to the construction of a Criminal Law according to the social reality.
\end{abstract}

Keywords: Criminal Law. Social adequacy. Theory of crime. Legal hermeneutics. Jurisprudence. 


\section{SUMÁRIO}

INTRODUÇÃO....................................................................................................................15

1 A TEORIA DA ADEQUAÇÃO SOCIAL: ASPECTOS GERAIS...............................19

$1.1 \mathrm{O}$ conceito de adequação social ..................................................................................19

1.2 Adequação social e o Finalismo .....................................................................28

1.3 Adequação social: uma regra, um princípio ou uma teoria? ..............................33

1.4 Adequação social e a teoria do delito.............................................................38

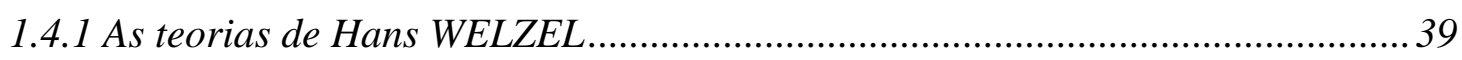

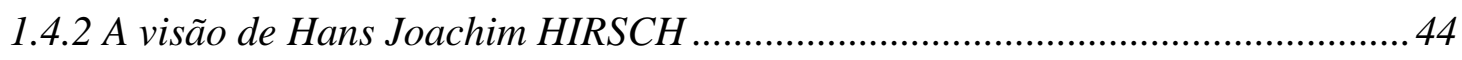

1.4.3 O pensamento de Claus ROXIN …..................................................................... 46

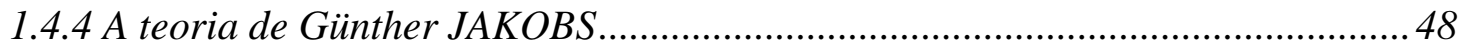

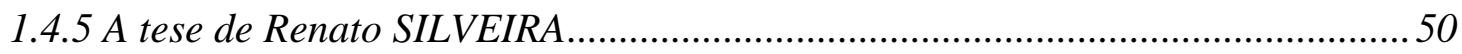

2 A ADEQUAÇÃO SOCIAL NO DIREITO PENAL: ASPECTOS ESPECÍFICOS.52

2.1 Adequação social e bem jurídico ...............................................................52

2.2 Adequação social e imputação objetiva...............................................................55

2.3 Adequação social e o princípio da insignificância ...............................................62

2.4 Ações socialmente adequadas, socialmente exemplares e socialmente habituais

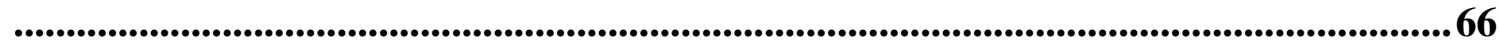

2.5 A violência desportiva.................................................................................69

2.5.1 Os fundamentos da violência desportiva.............................................................69

2.5.2 Adequação social e a violência desportiva ......................................................... 72

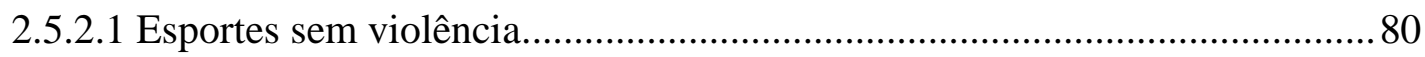

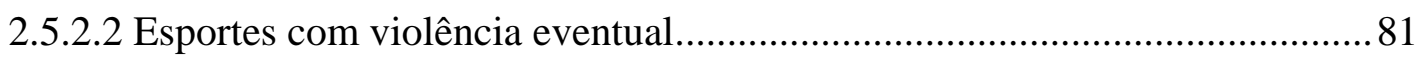

2.5.2.3 Esportes com violência necessária........................................................ 82

2.5.3 Breves considerações sobre a violência moral no esporte ..................................8 84

2.6 “Adequação social local”, “adequação social regional” e o multiculturalismo..88

2.7 Críticas à adequação social .......................................................................................................96

2.7.1 A desnecessidade, generalidade e imprecisão da teoria ..................................... 96

2.7.2 Adequação social e o princípio da legalidade .................................................. 104

2.7.3 Adequação social e segurança jurídica .......................................................... 107

3 INTERPRETAÇÃO JURISPRUDENCIAL DA TEORIA DA ADEQUAÇÃO SOCIAL: UMA ANÁLISE À LUZ DOS JULGADOS DO TRIBUNAL DE JUSTIÇA

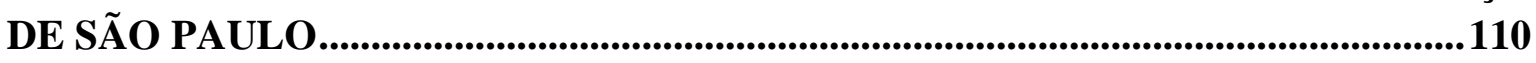


3.2.1 A teoria da adequação social na jurisprudência: inquietações e primeiras escolhas

3.2.2 Métodos de análise

3.2.3 Coleta de dados. 118

3.3 Da pesquisa quantitativa 122

3.3.1 Um panorama geral dos julgados 122

3.3.2 As infrações penais em análise 127

3.3.3 Adequação social como fundamento das decisões 131

3.3.4 Conclusões parciais. 136

\subsection{Da pesquisa qualitativa} 137

3.4.1 Adequação social e o crime de casa de prostituição 138

3.4.1.1 Adequação social e a revogação de normas penais 138

3.4.2 Adequação social e os crimes patrimoniais 140

3.4.2.1 Adequação social como técnica de descriminalização pela via interpretativa 140

3.4.2.2 Adequação social, o princípio da insignificância e a contextualização social da conduta

3.4.2.3 Adequação social e a revogação dos tipos penais 144

3.4.2.4 Adequação social e os prejuízos causados 144

3.4.3 Adequação social e o crime de violação de direito autoral. 145

3.4.3.1 Adequação social e a ausência de previsão legal. 147

3.4.3.2 Adequação social e a conduta socialmente habitual, tolerância social e falta de fiscalização do Poder Público 148

3.4.3.3 Adequação social e o princípio da insignificância. 150

3.4.3.4 Adequação social e o erro de proibição 151

3.4.3.5 Adequação social como excludente de ilicitude 153

3.4.3.6 Adequação social e a ofensa a bem jurídico 154

3.4.3.7 Adequação social como ferramenta destinada apenas ao Poder Legislativo

3.4.3.8 A "inadequação social” dos comportamentos analisados 156

3.4.3.9 Adequação social e os prejuízos causados 157

3.4.3.10 Adequação social e a revogação do tipo penal 158

3.4.3.11 A reprodução do entendimento dos Tribunais Superiores 159 
4 CONSIDERAÇÕES CRÍTICAS FRENTE À ANÁLISE DA TEORIA DA ADEQUAÇÃO SOCIAL PELA JURISPRUDÊNCIA DO TRIBUNAL DE JUSTIÇA

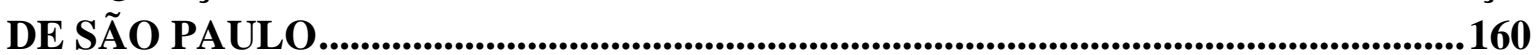

4.1 Erros do julgador na aplicação da teoria da adequação social: um panorama geral ............................................................................................................................ 160

4.1.1 A deturpação do significado de "adequação social".......................................... 161

4.1.2 A desconsideração das peculiaridades do caso concreto ................................... 166

4.1.3 A adequação social como violadora do princípio da legalidade e da segurança

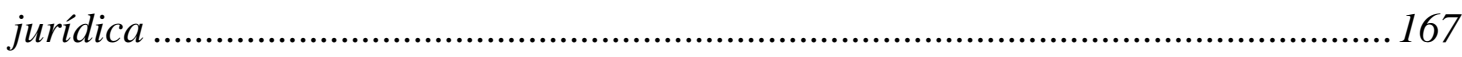

4.1.4 A impossibilidade de aplicação da teoria da adequação social na fase judicial

4.1.5 Adequação social como critério de exclusão da responsabilidade civil............177

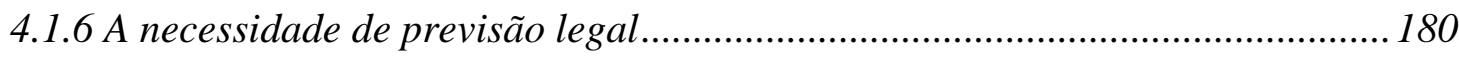

4.2 Critérios para a aplicação da teoria da adequação social: a identificação de comportamentos socialmente adequados...................................................................... 183

4.3 Bases para a construção de um Direito Penal em consonância com a realidade

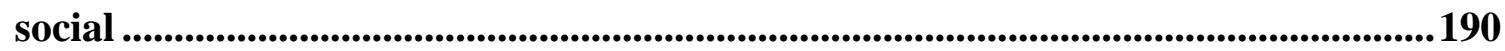

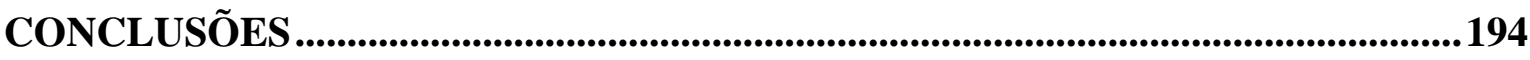

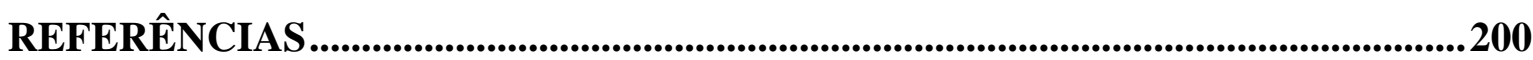

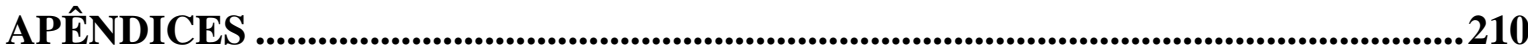




\section{INTRODUÇÃO}

As bases que justificam a existência de normas com caráter sancionador penal sempre estiveram intimamente vinculadas à realidade social vigente em cada época histórica, o que explica o fato de as funções desempenhadas pelo Direito Penal terem como fundamento a existência de uma sociedade organizada e estruturada de determinada maneira. Nesse sentido, como já acentuava BATISTA, para se compreender o direito dos romanos ou dos brasileiros no século XIX, basta que se analise como tais povos viviam e se organizavam para a produção e distribuição de bens e mercadorias nesse período ${ }^{1}$. Podese afirmar, então, que, não obstante seja o Direito Penal modelado pela sociedade, é também por ela influenciado e com ela interage.

Diante dessas observações, não há dúvidas de que a concepção do que se tem por socialmente adequado em determinada realidade social, aliada aos reflexos advindos dessa temática no âmbito jurídico, nunca foi algo incontroverso e pacífico entre doutrinadores e magistrados.

A ideia de adequação social surgiu pela primeira vez em 1939, idealizada pelo penalista alemão Hans WELZEL. O autor partiu da premissa de que uma conduta, para ser penalmente sancionada, necessita de reprovação social. Não basta que o comportamento do agente lesione ou ponha em perigo um bem jurídico tutelado pelo Direito Penal, mas é necessário, sobretudo, que haja uma valoração social negativa da conduta em análise, de modo a justificar a intervenção do aparelho repressivo do Estado. Assim, a criminalização de determinado comportamento somente será legítima caso esteja em consonância com os valores sociais vigentes.

Nessa linha de raciocínio, a justificativa para a construção do social e do adequado em Direito Penal se baseia no fato de que os sistemas jurídico e social são interligados e correlacionados. Dada intervenção mínima do Direito Penal na vida social, seria perfeitamente justificável a exigência de que os comportamentos individuais encontrassem respaldo nos valores extraídos da sociedade, até mesmo como meio de promoção da tarefa preventiva a que o Direito Penal se propõe ${ }^{2}$. De nada adiantaria a produção legislativa visando à tutela de um bem jurídico, se as condutas dos membros de uma comunidade não se pautassem nos valores explicitados na norma.

\footnotetext{
${ }^{1}$ BATISTA, Nilo. Introdução crítica ao direito penal brasileiro. Rio de Janeiro: Revan, 2011, p. 19.

${ }^{2}$ GOMES, Mariângela Gama de Magalhães. O princípio da proporcionalidade no direito penal. São Paulo: Revista dos Tribunais, 2003 p. 129.
} 
Por conseguinte, não há dúvida de que a teoria welzeliana constitui um instrumento de valor, sobre o qual se procede uma avaliação tanto do bem jurídico, como também da adequação típica. É inadmissível que uma realidade socialmente adequada possa fazer parte do conceito material de delito.

E esse estudo ganha relevância quando se considera que o Direito Penal, enquanto ultima ratio, não pode estar desvinculado da sociedade, uma vez que a tarefa preventiva somente será realizada com êxito caso as normas sancionadoras de cunho criminal estejam respaldadas nos valores sociais vigentes.

Com base em todas as construções doutrinárias ao longo dos seus quase oitenta anos de vida, a adequação social foi aceita por alguns, recusadas por outros, mas dificilmente ignorada nos manuais e escritos de Direito Penal ${ }^{3}$.

Por essa razão, ao se realizar um estudo mais detido e aprofundado deste instituto jurídico, é absolutamente necessário, em um primeiro momento, que se analise o seu conceito e as suas bases, expondo as principais discussões atinentes à sua aplicação no âmbito penal. Assentadas essas premissas, parte-se para a análise de como a jurisprudência vem aplicando ou afastando a aplicação da consagrada teoria no Direito Penal, até mesmo como norte para a interpretação de diversas modalidades delitivas existentes no ordenamento jurídico brasileiro.

Com um panorama geral das discussões doutrinária e jurisprudencial, será possível visualizar o real tratamento dado à adequação social pelo sistema jurídico-penal como um todo. E, então, haverá elementos suficientes para que sejam tecidas considerações críticas, propondo-se, ao final, critérios para uma efetiva aplicação da teoria da adequação social no Direito Penal.

Por isso é que, no primeiro capítulo deste trabalho, optou-se por abordar os aspectos mais gerais do instituto. O propósito é realizar uma exposição do seu conceito, origem e natureza jurídica. Nesse momento, também será analisada a sua inserção na teoria tripartida do delito, tendo como elementos a tipicidade, antijuridicidade e culpabilidade. Tendo em vista os propósitos e limites desta pesquisa, não se pretende desenvolver longos percursos doutrinários sobre o tema, até porque já há trabalhos específicos que se dedicam

\footnotetext{
${ }^{3}$ RIBEIRO DE FARIA, Maria Paula Bonifácio. A adequação social da conduta no direito penal ou o valor dos sentidos sociais na interpretação da lei penal. Porto, Ed. Universidade Católica, 2005, p. 32.
} 
a essa tarefa ${ }^{4}$, para os quais se remete o leitor. Logo, a análise se circunscreverá aos aspectos mais relevantes e controvertidos da teoria welzeliana.

No segundo capítulo, e ainda sob o enfoque doutrinário, serão tratados alguns temas específicos relacionados à adequação social. Para tanto, a teoria será analisada à luz do bem jurídico, da imputação objetiva e do princípio da insignificância. Também se investigará a existência de uma identidade conceitual entre ações socialmente adequadas exemplares e habituais. E não há como trabalhar com essas questões, sem fazer menção a um dos exemplos mais recorrentes, e também dos mais problemáticos, envolvendo a teoria da adequação social: a violência desportiva.

$\mathrm{Na}$ sequência, serão feitas breves considerações sobre o multiculturalismo. O objetivo é verificar a possibilidade de se sustentar, ainda hoje, a existência de comportamentos socialmente adequados em uma realidade permeada por múltiplos valores e manifestações culturais em um mesmo quadrante espaço-temporal. Por fim, mostra-se igualmente relevante a abordagem das principais críticas concernentes à teoria em apreço, seja em razão da sua desnecessidade, generalidade e imprecisão, seja pela sua relação com o princípio da legalidade e com a segurança jurídica.

Dado esse primeiro passo, no terceiro capítulo, partir-se-á para uma análise jurisprudencial. Primeiramente, serão feitas considerações acerca da importância de se estudar a adequação social à luz da jurisprudência. Após, será construída uma metodologia de pesquisa empírica, para que, então, as decisões sejam analisadas.

Este trabalho se propõe a expor dados quantitativos dos julgados, a fim de que se tenha uma base do número de decisões e da natureza dos crimes ou contravenções nos quais há discussão envolvendo a aplicação da adequação social.

A pesquisa quantitativa fornecerá subsídios para uma análise qualitativa dos acórdãos. Com base nas infrações penais levantadas, será feita uma exposição dos argumentos empregados pelos magistrados para aplicar ou rejeitar a teoria. Aqui já se vislumbra a importância da primeira parte da dissertação ao delinear as principais discussões doutrinárias sobre a temática tratada.

Adianta-se, desde logo, que o intuito desse estudo não é verificar uma suposta adequação social dos crimes e contravenções pesquisados. Para tanto, entrariam em cena outros aspectos relevantes e que fogem ao âmbito da pesquisa, como a evolução sociocultural brasileira em relação a dado comportamento. Além de complexa, essa

\footnotetext{
${ }^{4}$ A título exemplificativo, citem-se: RIBEIRO DE FARIA, op. cit; SILVEIRA, Renato de Mello Jorge. Fundamentos da adequação social em direito penal. São Paulo: Quatier Latin, $1^{a}$ ed., 2010.
} 
temática demanda pesquisa e estudo específicos, mediante a obtenção de dados empíricos. Esta dissertação, ao contrário, propõe-se a fornecer um norte mais abrangente a respeito de como os aplicadores do Direito têm analisado a teoria da adequação social.

No quarto e último capítulo, em vista de todo o cenário construído, serão tecidas considerações críticas ao tratamento dispensado à adequação social na jurisprudência, à luz dos principais erros cometidos pelo julgador. Finalmente, propor-se-ão alguns critérios para a identificação do socialmente adequado no Direito Penal. Tem-se como meta a busca de soluções para a construção de um Direito Penal mais próximo da realidade sociocultural. 


\section{CONCLUSÕES}

1. A adequação social ganha sentido enquanto diretriz normativa do sistema jurídico-penal, na medida em que se compreende a íntima vinculação entre a estrutura da norma penal e os sistemas sociais. Deve ser entendida como uma ferramenta hermenêutica, por meio da qual são excluídos determinados comportamentos que, avaliados sob uma perspectiva extrassistêmica e em função de sua utilidade social, estejam em consonância com a ordem histórico-cultural vigente.

2. Quando se analisa a natureza jurídica da adequação social, é de se considerá-la verdadeira "teoria" jurídica, na medida em que se propõe como método de interpretação histórico-dinâmico dos tipos penais, fornecendo princípios para a delimitação do conteúdo da norma. Nada obstante, tal ferramenta se aplica especificamente à seara penal, pois se alicerça fundamentalmente na danosidade social do comportamento, com reflexos no campo criminal.

3. Em que pesem as mudanças de entendimento de WELZEL quanto à inserção da adequação social na teoria do delito (em um primeiro momento, como critério de valoração social da ação e excludente do tipo; posteriormente, como causa de justificação consuetudinária; e, finalmente, como ferramenta interpretativa da norma penal), deve-se dar razão a SILVEIRA, ao defender que se trata de um instrumento hermenêutico que realiza um exame social prévio à tipicidade, não permitindo o seu aperfeiçoamento.

4. Considerando que a existência humana pressupõe riscos a bens jurídicos penalmente relevantes, não há como vedar a realização de todo comportamento que lhes importe perigo de lesão. Nesse sentido, está equivocada a ideia de que uma ação socialmente adequada não ofende bens jurídicos dignos de proteção penal. O fundamento da teoria da adequação social reside no fato de haver relações entre esses bens que supõem o desenvolvimento de uma função positivamente valorada no marco da vida social.

5. Ainda que alguns autores tentem desmerecer a adequação social frente à teoria da imputação objetiva, verifica-se que ambas podem conviver harmonicamente em um mesmo ordenamento jurídico-penal. Por meio de uma análise extrassistêmica e prévia ao tipo, pondera-se o caráter socialmente adequado de determinada ação, com bases histórico-ético-valorativas. Se o resultado for negativo, passa-se à avaliação do risco permitido, que ampara a teoria da imputação objetiva. 
6. A teoria da adequação social ainda se diferencia do princípio da insignificância. Este constitui um critério hermenêutico intrassistêmico, pois pressupõe a ínfima ofensa ao bem jurídico tutelado, centrando-se fundamentalmente no desvalor do resultado. Aquela, por sua vez, avalia, de modo extrassistêmico, a aprovação da sociedade em relação à determinada conduta, referindo-se muito mais ao desvalor da ação.

7. Ações socialmente adequadas não se confundem com ações socialmente exemplares ou habituais. Aquelas decorrem de uma contínua percepção histórico-cultural de uma generalidade de pessoas quanto à adoção de determinado comportamento. Ou seja, há na ação socialmente adequada uma coincidência de valores que animam o agente com aqueles desejados pela sociedade, ainda que não sejam usuais ou exemplares.

8. Uma das aplicações práticas mais recorrentes da teoria da adequação social encontra espaço no campo desportivo. Inúmeras são as funções desempenhadas pelo desporto no seio social: ele intensifica a comunicação dos integrantes de uma comunidade, contribui para a educação e disciplina e representa um meio de celebração ritualizada do corpo e promoção da saúde. Nesse contexto, não há dúvidas de que condutas amparadas em regras desportivas, ainda que provoquem resultados lesivos a bens jurídicos penalmente tutelados, devam ser tidas como socialmente adequadas. Isso se justifica, porque, de um ponto de vista extrassistêmico, elas integram o acervo histórico-cultural da sociedade.

9. Para análise das condutas que não observam as regras desportivas, faz-se necessário dividir as modalidades entre três grupos: (i) esportes sem violência; (ii) esportes com violência eventual; (iii) esportes com violência necessária. No primeiro grupo, encontram-se aquelas modalidades em que não há contato entre os jogadores. Por isso, eventuais lesões provocadas não se inserem no âmbito normal da partida e não podem ser tidas como socialmente adequadas. No segundo grupo, situam-se aqueles esportes que há contato eventual entre os competidores, ainda que não seja essa a regra. Está amparado pela adequação social todo comportamento que integre o desenvolvimento regular do jogo, embora em descordo com o código normativo correspondente. No entanto, manifestações ofensivas que não se inserem no andamento normal da partida não são socialmente adequadas e exigem, a depender do caso, a intervenção punitiva do Estado. Por fim, há uma tolerabilidade social maior quanto às lesões provocadas em modalidades integrantes do terceiro grupo, haja vista que os atletas estão em constante contato físico. Salvo nos casos envolvendo graves infrações às regras do jogo, levando a resultados lesivos não integrantes do regular andamento da partida, as condutas dos competidores devem ser tidas como socialmente adequadas. 
10. No que concerne à violência moral no esporte, a adequação social se mostra como melhor resposta dogmática aos insultos, palavrões e gestos obscenos praticados no contexto desportivo. Em uma avaliação pré-típica, determinadas manifestações ofensivas à honra dos jogadores integram o desenvolvimento regular da partida, especialmente em momentos de fervor e angústia. Embora determinadas práticas injuriosas possam ser aceitas se não ultrapassarem os limites normais do jogo e não atentarem contra a dignidade da pessoa humana, a situação se inverte quando se trata de racismo. Em vista do âmbito comunicacional aberto deste tipo de crime, estendendo-se a ofensa a uma coletividade de pessoas pertencentes à mesma raça, a conduta do agressor nunca poderá ser respaldada pela adequação social.

11. O cenário político-social atual é marcado fortemente pelo multiculturalismo, no qual diversas culturas coexistem no mesmo quadrante espaço-temporal, devendo, na medida do possível, ser respeitadas. Considerando o Brasil como um país de dimensões territoriais consideráveis, inúmeras manifestações culturais, se avaliadas sob uma perspectiva global, seriam tidas como violadoras de princípios e regras constitucionais, ao passo que, à luz de um grupo social específico, poderiam ser vistas como lícitas. $\mathrm{Na}$ avaliação do socialmente adequado, deve-se ter como baliza o princípio da dignidade humana, em caráter individual. Manifestações que violem direitos humanos fundamentais não podem ser toleradas no seio social, ainda que contem com a aprovação de alguns indivíduos ou grupos de pessoas.

12. Grande parte das objeções quanto à adequação social diz respeito à sua imprecisão, desnecessidade e generalidade. No entanto, essas críticas não merecem respaldo, haja vista que a teoria se propõe a analisar os condicionantes históricos e culturais de uma comunidade, para que se possa extrair, de um ponto de vista extrassistêmico, o que se tem por socialmente tolerável. Um dos exemplos de sua aplicação no Direito Penal moderno diz respeito ao campo econômico. A intitulada "adequação econômica da conduta" baseia-se na teoria welzeliana para avaliar os comportamentos dos agentes econômicos no âmbito concorrencial.

13. Também não se justificam as críticas que tomam a adequação social como instrumento violador do princípio da legalidade e da segurança jurídica. A máxima do nullum crimen, nulla poena sine lege não significa que haja tolerância a leis manifestamente injustas e alheias às concepções e transformações sociais. Outrossim, a certeza do direito não pressupõe o monopólio da lei. O aplicador da norma não se vincula à letra fria do texto legal, mas externa o seu entendimento por meio da interpretação dos 
tipos à luz das normas principiológicas que norteiam o sistema punitivo. A adequação social se propõe, nesse contexto, a limitar a ingerência estatal indevida sobre a esfera da liberdade individual, reconstruindo o conteúdo da incriminação com lastro na vida social. Com isso, reforça-se o ideal de certeza do direito, permitindo que ele esteja em consonância com os valores comunitários.

14. A pesquisa quantitativa realizada com base nos acórdãos do Tribunal de Justiça de São Paulo permitiu que se traçassem alguns perfis da sua Seção Criminal. Verificou-se uma tendência das turmas julgadoras em acolher integralmente os argumentos do relator, julgando o recurso por unanimidade. Ainda se notou uma feição mais punitivista da Corte Paulista, considerando que as teses acusatórias ganharam mais respaldo do que as defensivas e, consequentemente, o número de condenações mantidas superou em muito o de sentenças absolutórias não reformadas.

15. A análise quantitativa dos julgados ainda revelou a importância da adequação social como argumento defensivo no tocante ao delito de violação de direito autoral. $\mathrm{O}$ fato de $83,44 \%$ de todas as decisões pesquisadas referirem-se ao crime do artigo 184 do Código Penal sinaliza, ao menos sob o ponto de vista defensivo, que as condutas formalmente tipificadas no dispositivo seriam toleradas sob a ótica social. Também se notou uma resistência do Tribunal em aplicar a teoria da adequação social aos casos julgados, considerando que todos os acórdãos, de um modo ou de outro, deixaram de acolher o referido instrumento hermenêutico como tese absolutória. Cinco deles, embora não tenham feito menção expressa à teoria welzeliana, acabaram se valendo de seus fundamentos para absolver ou manter a absolvição dos réus.

16. A análise qualitativa dos acórdãos expôs os inúmeros argumentos empregados pelos magistrados para afastar a teoria da adequação social nos três crimes com maior incidência no banco de dados (casa de prostituição, delitos patrimoniais e violação de direito autoral). Dentre as teses levantadas, destacam-se aquelas que consideram a adequação social como meio de revogação de tipos penais, ou que a confundem com o princípio da insignificância. Especialmente em relação ao crime do artigo 184 do Código Penal, constataram-se argumentos no sentido de que a teoria welzeliana não merece amparo judicial, pois inexiste previsão a seu respeito no ordenamento jurídico, ou que se trata de ferramenta destinada unicamente ao Poder Legislativo. Da mesma forma, em algumas decisões, houve uma notória confusão entre a adequação social e o erro de proibição, além de considerações equivocadas de que uma conduta socialmente aceita não pode ofender bem jurídico digno de tutela penal. 
17. Por meio da análise dos argumentos despendidos nos acórdãos, foi possível notar a falta de um verdadeiro embasamento teórico nas decisões, o que, de certa forma, pode ser explicado pela fácil apreensão do termo "adequação social". O "adequado socialmente" é tudo aquilo que a sociedade aprova, ou que não merece a rejeição dos seus membros. Isso propicia a invocação de uma infinidade de teses e argumentos genéricos que sequer guardam pertinência com o instrumento hermenêutico em destaque. Portanto, ao se transpor o conceito de "adequação social" para o âmbito da jurisprudência, ele acaba se tornando fluido e vulgarizado, sem uma verdadeira racionalidade. A teoria welzeliana passa a ser vista muito mais como uma ferramenta de decisão do que propriamente com um instrumento jurídico racional e em consonância com o discurso jurídico-penal. Todavia, a jurisprudência não pode ignorar a evolução e o as bases da adequação social, na medida em que representa, em boa medida, uma relevante fonte de criação jurídica.

18. Nesse contexto, a adequação social deve ser compreendida como uma ferramenta de interpretação sociológica restritiva dos tipos penais, rompendo com as estruturas formalísticas do Direito e permitindo uma releitura da norma a partir do fenômeno cultural. Ela não se propõe a revogar tipos penais, até porque o monopólio da produção normativa pertence ao Poder Legislativo. Do mesmo modo, não pode ser entendida como violadora do princípio da legalidade e da segurança jurídica, na medida em que se propõe a aliar a estrita determinação dos tipos penais a um ideal de justiça, emprestando ao Direito Penal uma função dinamizadora.

19. A teoria da adequação social presta-se ainda à avaliação de comportamentos concretos. Não se vê com acerto o uso recorrente de expressões vagas e genéricas pela jurisprudência do Tribunal de Justiça de São Paulo, em tese aplicáveis a quaisquer hipóteses. Ao se realizar o juízo de adequação social de determinado comportamento, é preciso avaliar as características e peculiaridades do caso concreto.

20. Está equivocada a ideia de que a adequação social afasta a responsabilidade civil. A teoria se aplica especificamente ao âmbito criminal, permitindo a exclusão do injusto em uma verificação pré-típica. Isso significa que uma conduta socialmente adequada, caso tenha dado causa a algum prejuízo, pode ensejar uma pretensão indenizatória no âmbito cível.

21. Deve a teoria welzeliana servir como parâmetro tanto ao legislador, no momento de selecionar os modelos de conduta proibidos, quanto ao julgador, durante a interpretação dos tipos penais. Portanto, a adequação social é um instrumento que se destina às esferas legislativa e judiciária. 
22. A ausência de previsão legal não deve obstar o reconhecimento e a aplicação da teoria welzeliana. Fosse assim, inúmeros instrumentos hermenêuticos não positivados na ordem jurídica, como a insignificância, não contariam com o devido respaldo jurisprudencial. No entanto, a par da sua relevância, e a fim de evitar teses que excluam a sua aplicação pelo fato de não estar prevista no ordenamento, deveria o legislador dispô-la no texto constitucional ou na Parte Geral do Código Penal.

23. Ao se avaliar a aplicabilidade da adequação social em um caso concreto, não podem servir como referências a mera opinião do operador do Direito e a expressão quantitativa de apoio social à conduta valorada. Critérios como a formação da opinião pública, o interesse histórico, cultural e científico, a utilidade social do comportamento e o respeito ao princípio da dignidade da pessoa humana são os que melhor propiciam a identificação do socialmente adequado.

24. Em suma, no curso da evolução social, ocorrem inúmeras modificações nas circunstâncias e nos valores sociais. A lei é incapaz de acompanhar a evolução dos fatos e de atender às novas necessidades emergentes. É por isso que se torna indispensável o emprego de uma ferramenta hermenêutica que conecte o Direito Penal a essa realidade, inserindo nos critérios de valoração de condutas concretas referências aos aspectos históricos, sociais e culturais de uma comunidade. Daí a relevância e imprescindibilidade da teoria da adequação social. 


\section{REFERÊNCIAS}

ALEXY, Robert. Teoría de los derechos fundamentales. Madrid: Centro de estudios políticos y constitucionales, 2002.

AMBOS, Kai. Sobre os fins da pena nos níveis nacional e supranacional. Porto Alegre: Sérgio Antônio Fabris, 2006.

ANDRADE, Manuel da Costa. As lesões corporais (e a morte) no desporto. Revista Brasileira de Ciências Criminais, São Paulo, v. 14, n. 59, mar./abr. 2006, p. 128-183.

ANDREUCCI, Ricardo Antunes. Da incriminação do adultério. Tese de doutorado apresentadas à Faculdade de Direito da USP, 1967.

APPIAH, K. Anthony. Identity, authenticity, survival. Multicultural societies and social reproduction. In: TAYLOR, Charles (org.). Multiculturalism. Examining the politics of recognition. Princeton, New Jersey, 1994, p. 149-163.

ÁVILA, Humberto. Teoria dos princípios: da definição à aplicação dos princípios jurídicos. São Paulo: Malheiros Editores, 2008.

BACIGALUPO, Enrique. Principios constitucionales de derecho penal. Buenos Aires: Hammurabi, 1999.

BADARÓ, Gustavo Henrique Righi Ivahy. Processo penal. São Paulo: Campus Jurídico, $1^{a}$ ed., 2012.

BATISTA, Nilo. Introdução crítica ao direito penal brasileiro. Rio de Janeiro: Revan, 2011.

BECCARIA, Cesare. Dos delitos e das penas. Tradução de Paulo M. Oliveira. São Paulo: Edipro, $1^{\text {a }}$ ed., 2003.

BECHARA, Ana Elisa Liberatore Silva. Bem jurídico-penal. São Paulo: Quartier Latin, ${ }^{\text {a }}$ ed., 2014.

BEM, Leonardo Schmitt de. Direito Penal Desportivo: homicídios e lesões no âmbito da prática desportiva. São Paulo: Quartier Latin, $1^{\mathrm{a}}$ ed., 2009.

; Paternalismo penal e esportes radicais. In: BEM, Leonardo Schmitt de; VICENTE MARTÍNEZ, Rosario de. Direito desportivo e conexões com o direito penal. São Paulo: Juruá, 2014, p. 549-555.

BETTIOL, Giuseppe. Objetivismo e subjetivismo no âmbito da noção de delito. Revista Brasileira de Criminologia e Direito Penal, Rio de Janeiro, v. 3, n. 9, abr./jun. 1965, p. 2334.

BITENCOURT, Cezar Roberto. Tratado de direito penal: parte geral, vol. 1. São Paulo: Saraiva, $14^{\mathrm{a}}$ ed., 2009. 

2000.

; MUÑOZ CONDE, Francisco. Teoria geral do delito. São Paulo: Saraiva, $1^{\mathrm{a}}$ ed.,

BITTAR, Eduardo C. B. Metodologia da pesquisa jurídica: teoria e prática da monografia para os cursos de direito. São Paulo: Saraiva, $5^{\text {a }}$ ed., 2007.

BLANCO CORDERO, Isidoro. Negocios socialmente adecuados y delito de blanqueo de capitales. Anuario de derecho penal y ciencias penales, Madrid, v. 50, único, jan./dez. 1997, p. 263-291.

BOTTINI, Pierpaolo Cruz. A confusa exegese do princípio da insignificância. In: RASCOVSKI, Luiz (coord.). Temas relevantes de direito penal e processual penal. São Paulo: Saraiva, $1^{\mathrm{a}}$ ed., 2012.

BUJAN, Javier Alejandro; DE LANGHE, Marcela. Tratado de los delitos: delitos contra las personas, tomo 1. Buenos Aires: Ábaco de Rodolfo Depalma, 2004.

CAMARGO, Antônio Luís Chaves. Imputação objetiva e direito penal brasileiro. São Paulo: Cultural Paulista, $1^{\mathrm{a}}$ ed., 2002.

CANCIO MELIÁ, Manuel. La teoria de la adecuación social en Welzel. Anuario de Derecho Penal y Ciencias Penales, Madrid, vol. 46, n. 2, mai./ago. 1993, p. 697-729.

Teoría final de la acción e imputación objetiva: consideraciones sobre la teoría de la adecuación social. Revista Brasileira de Ciências Criminais, São Paulo, v. 13, n. 55, jul./ago. 2005, p. 135-161.

CANOTILHO, J. J. Gomes. Direito constitucional e teoria da Constituição. Coimbra: Almedina, 2003.

CARRARD, Liliana. $O$ princípio da insignificância e a mínima intervenção penal. Dissertação de Mestrado apresentada à Faculdade de Direito da Universidade de São Paulo, 2013.

CARVALHO, Márcio Augusto Friggi. Princípio da adequação social: ponderações quanto à autonomia em contexto funcionalista. Boletim IBCCRIM, São Paulo, v. 21, n. 246, 2013, p. 5-6.

CARVALHO, Salo de. Como não se faz um trabalho de conclusão. São Paulo: Saraiva, $2^{\mathrm{a}}$ ed., 2013.

CASTRO, Henrique Hoffmann Monteiro de. Princípios da fragmentariedade e da adequação social e crime de casa de prostituição. Revista Jurídica do Ministério Público do Estado de Minas Gerais, Belo Horizonte, v. 11, nº 18, jan./jun. 2012, p.163-177.

CATÃO, Yolanda. Notas sobre a punição do adultério e descriminalização. Revista de Direito Penal, n. 13/14, jan./jun. 1974.

CEREZO MIR, José. Derecho penal: Parte General. São Paulo: RT, 1ª ed., 2007. 
La influencia de Welzel y del finalismo, en general, en la Ciencia del Derecho penal española y en la de los países iberoamericanos. Anuario de derecho penal y ciencias penales, Madrid, v. 62, único, jan./dez. 2009, p. 67-92.

. Ontologismo y normativismo en el finlismo de los años cincuenta. In: HIRSCH, Hans Joachim; CEREZO MIR, José; DONNA, Edgardo Alberto (orgs.). Hans Welzel en el pensamiento penal de la modernidad: homenaje en el centenario del nacimiento de Hans Welzel. Buenos Aires: Rubinzal-Culzoni, 2005, p. 47-65.

CORRÊA, Getúlio. O princípio da adequação social na estrutura jurídica do crime. Dissertação de Mestrado apresentada à Universidade Federal de Santa Catarina, 1991.

COSTA, Domingos Barroso da. Da modernidade à pós-modernidade, do positivismo ao pós-positivismo: sobre a exposição da crise de legitimidade do sistema penal brasileiro pelas transformações da sociedade e do direito. Revista Brasileira de Ciências Criminais, São Paulo, v. 20, n. 94, jan./fev. 2012, p. 321-344.

COSTA, Helena Regina Lobo da. Proteção ambiental, direito penal e direito administrativo. Tese de Doutorado apresentada à Faculdade de Direito da Universidade de São Paulo, 2007.

. A dignidade humana: teorias de prevenção geral positiva. São Paulo: RT, 2008.

. Direito Penal Econômico e Direito Administrativo Sancionador: ne bis in idem

como medida de política sancionadora integrada. Tese de Livre-Docência apresentada à Faculdade de Direito da Universidade de São Paulo, 2013.

DWORKIN, Ronald. Levando os direitos a sério. Trad. Nelson Boeira. São Paulo: Martins Fontes, $2^{\mathrm{a}}$ ed., 2007.

ESER, Albin. La adecuación social: figura legal superflua o necesaria?. Revista de Derecho Penal, Buenos Aires, nº 1, 2002.

. Deporte y justicia penal. Revista Penal, Valencia, n. 6, jul. 2000, p. 53-66.

FARALDO CABANA, Patricia. Consentimiento y adecuación social en los delitos contra los consumidores. Intertemas. Revista do Curso de Mestrado em Direito, Presidente Prudente, v. 2, n. 2, dez. 2001, p.11-32.

FEFERBAUM, Marina; PALMA, Juliana Bonacorsi; PINHEIRO, Victor Marcel. Meu trabalho precisa de jurisprudência? Como posso utilizá-la? In: FEFERBAUM, Marina; QUEIROZ, Rafael Mafei Rabelo (orgs.). Metodologia jurídica: um roteiro prático para trabalhos de conclusão de curso. São Paulo: Saraiva, 2015, p. 139-173.

FIANDACA, Giovanni; MUSCO, Enzo. Diritto penale: parte speciale, v. 1. 2. ed. Bologna: Zanichelli, $4^{\mathrm{a}}$ ed., 2013.

FIGUEIREDO DIAS, Jorge de. O problema da consciência da ilicitude em direito penal. Coimbra: Coimbra Editora, $5^{\text {a }}$ ed., 2000.

FIORE, CARLO. L'azione socialmente adeguata nel diritto penale. Napoli: Morano, 1966.

GARCEZ NETO, Martinho. Função criadora da jurisprudência. In Revista EMERJ, v. 5, $\mathrm{n}^{\circ} 19,2002$, p. 46 a 52. 
GIL GIL, Alicia. Sobre la pertenencia del desvalor del resultado a lo injusto. In: HIRSCH, Hans Joachim; CEREZO MIR, José; DONNA, Edgardo Alberto (orgs.). Hans Welzel en el pensamiento penal de la modernidad: homenaje en el centenario del nacimiento de Hans Welzel. Buenos Aires: Rubinzal-Culzoni, 2005, p. 389-408.

GOMES, Luis Flávio. Princípio da insignificância e outras excludentes de tipicidades. São Paulo: Revista dos Tribunais, 2009.

GOMES, Mariângela Gama de Magalhães. Direito Penal e Interpretação Jurisprudencial: do princípio da legalidade às súmulas vinculantes. São Paulo: Atlas, $1^{\text {a }}$ ed., 2008.

Notas sobre as súmulas vinculantes em matéria penal. Revista Brasileira de Ciências Criminais, São Paulo, v. 18, nº 84, mai/jun. 2010, p. 77-110.

- O princípio da proporcionalidade no direito penal. São Paulo, Revista dos Tribunais, $1^{\mathrm{a}}$ ed., 2003.

. Teoria geral da parte especial do direito penal. São Paulo: Atlas, $1^{\text {a }}$ ed., 2013.

GRACIA MARTÍN, Luis. Fundamentos de dogmática penal. Una introducción a La concepción finalista de la responsabilidad penal. Barcelona: Atelier, 2006.

O finalismo como método sintético real-normativo para a construção da teoria do

delito. Ciências Penais: Revista da Associação Brasileira de Professores de Ciências Penais, São Paulo, v. 2, n. 2, jan./jun. 2005, p. 5-28.

. O horizonte do finalismo e o direito penal do inimigo. Tradução de Luiz Regis Prado e Érika Mendes de Carvalho. São Paulo: Revista dos Tribunais, $1^{\mathrm{a}}$ ed., 2007.

GRECO, Luís. Cumplicidade através de ações neutras. A imputação objetiva na participação. Rio de Janeiro, $1^{\text {a }}$ ed., 2004. 2013.

. Um panorama da imputação objetiva. São Paulo: Revista dos Tribunais, $4^{\mathrm{a}}$ ed.,

GRECO FILHO, Vicente. Imputação objetiva: o que é isso? Disponível em $<$ http://www.ibccrim.org.br/artigo/972-Artigo-Imputacao-objetiva-o-que-e-isso>. Acesso em 07/04/2016.

GUARAGNI, Fábio André. As teorias da conduta em direito penal. Um estudo da conduta humana do pré-causalismo ao funcionalismo pós-finalista. São Paulo: Revista dos Tribunais, 2005.

GUZMÁN DÁLBORA, José Luis. Bien jurídico y norma de cultura: revisión de la teoría de Max Ernst Mayer. Revista de derecho penal y criminología: Espanha, Madrid, n. 3, 1993, p. 227-240.

FERRAJOLI, Luigi. Direito e razão: Teoria do garantismo penal. São Paulo: Revista dos Tribunais, $2^{\mathrm{a}}$ ed., 2006.

HASSEMER, Winfried; MUÑOZ CONDE, Francisco. Introducción a la criminología y al derecho penal. Valencia: Tirant lo Blanch, 1989. 
HERRERA MORENO, Myriam. Multiculturalismo y tutela penal: a propósito de la problemática sobre la mutilación genital femenina. Revista de derecho penal y procesal penal, Buenos Aires, n. 6, jun. 2006, p. 1045-1061.

HIRSCH, Hans Joachim. Acerca de la crítica al finalismo. Anuario de derecho penal y ciencias penales, Madrid, v. 58, n. 1, jan./abr. 2005, p. 5-28.

Adecuación social y teoría del injusto. Derecho penal: obras completas: libro homenaje, Tomo III. Buenos Aires: Rubinzal-Culzoni, 2002.

JAKOBS, Günther. Cómo protege el derecho penal y qué es lo que protege? Contradicción y prevención; protección de bienes jurídicos y protección de la vigencia de la norma. In: YACOBUCCI, Guillermo Jorge (Dir.). Los desafíos del derecho penal en el siglo XXI: libro homenaje al profesor Dr. Günther Jacobs. Lima: Ara, 2005, p. 137-156.

Derecho penal: Parte general. Fundamentos y teoría de la imputación. Traducción de Joaquin Cuello Contreras y José Luis Serrano Gonzales de Murillo. Madrid: Marcial Pons, $2^{\mathrm{a}}$ ed., 1997.

. Fundamentos del derecho penal. Traducción de Manuel Cancio Meliá y Enrique Peñaranda Ramos. Buenos Aires: Ah Hoc, $1^{\text {a }}$ ed., 1996.

. ¿Qué protege el derecho penal: bienes jurídicos o la vigencia de la norma?. In: MONTEALEGRE LYNETT, Eduardo (Coord.). El funcionalismo en derecho penal: libro homenaje al profesor Günther Jakobs, v. I. Bogotá: Universidad Externado de Colombia, 2003, p. 39-56.

- Sociedad, norma, persona em uma teoría de um derecho penal funcional. Traducción de Manuel Cancio Meliá y Bernando Feijoó Sánchez. Madrid: Civitas, 1996.

LEISTER, Margareth Anne; TREVISAM, Elisaide. A tolerância e os direitos humanos: aceitar o multiculturalismo e as diversidades para viver uma cultura democrática. Revista direitos humanos fundamentais, Osasco, v. 12, n. 1, jan./jul. 2012, p. 199-227.

LEITÃO, Helena Martins. A mutilação genital feminina à luz do Direito Penal português: da necessidade de alteração do seu regime legal. Revista do Ministério Público de Lisboa, Lisboa, v. 34, n. 136, out./dez. 2013, p. 99-121.

LYRA, José Francisco Dias da Costa. A moderna sociedade do risco e o uso político do controle penal ou a alopoiesis do direito penal. Revista Brasileira de Ciências Criminais, São Paulo, v. 20, n. 95, mar./abr. 2012, p. 239-272.

LOPES, João. Justiça desportiva: ofensa à honra. Boletim do Instituto de Ciências Penais, Belo Horizonte, v. 8, nº 107, p. jan./mar. 2011, p. 6-7.

LUISI, Luiz. O tipo penal, a teoria finalista e a nova legislação penal. Porto Alegre: Fabris, 1987.

. Os princípios constitucionais penais. Bahia: Sérgio Antônio Fabris Editor, 1991.

MARTINELLI, João Paulo Orsini. Casa de prostituição: a adequação social e a moral pública. Revista Brasileira de Ciências Criminais, São Paulo, v. 22, nº 110, set./out. 2014, p.457-472. 
MASI, Carlo Velho. A superação do Direito Penal "clássico": tendências político-criminais na sociedade contemporânea. Revista Liberdades, São Paulo, n. 15, jan./abr. 2014, p. 4672.

MAYER, Max Ernst. Normas jurídicas y normas de cultura. Traducción del alemán y prólogo por José Luis Guzmán Dálbora. Buenos Aires: Hammurabi, 2000. . Derecho penal: parte general. Buenos Aires: B. de F., 2007.

MEIRIM, José Manuel. Ética desportiva: a vertente sancionatória pública. Revista Portuguesa de Ciência Criminal, Coimbra, v. 2, n. 1, jan./mar., 1992, p. 85-110.

MEJÍA, Enrique Ramos. El derecho penal y la acción socialmente adecuada. Nuevo Pensamiento Penal: Revista de derecho y ciencias penales, Buenos Aires, v. 3, 1974.

MIR PUIG, Santiago. El derecho penal en el estado social y democrático de derecho. Barcelona: Ariel, 1994. 2003. Introducción a las bases del derecho penal. Buenos Aires; Julio César Faria, $2^{\mathrm{a}}$ ed.,

MOCCIA, Sergio. El derecho penal entre ser y valor: función de la pena y sistemática teleológica, Montevidéu/Buenos Aires, Editorial IB, 2003.

MORALES PRATS, Fermín. Adecuacion social y tutela penal del honor: perspectiva despenalizadora. Cuadernos de política criminal, Madrid, no 36, 1988, p. 663-725.

MUNHOZ, Maria Letícia Puglisi; BRANDÃO, Juliana Ribeiro. Nas entrelinhas da distinção dos crimes de injúria racial e racismo. Boletim IBCCRIM, São Paulo, v. 24, n. 285, ago. 2016, p. 17-18.

NEVES, Sheilla Maria da Graça Coitinho das. A criminalidade na sociedade pós-moderna: globalização e tendências expansionistas do direito penal. Ciências Penais: Revista da Associação Brasileira de Professores de Ciências Penais, São Paulo, v. 3, n. 5, jul./dez. 2006, p. 284-304.

OLIVEIRA NETO, Olavo. Manual de Monografia Jurídica. São Paulo: Quartier Latin, $1^{\text {a }}$ ed., 2007.

OTTO, Harro. La adecuación social como principio de interpretación. Revista de Derecho Penal y Processual Penal, n. 10, out. 2012, p. 1706-1718.

PAREDES CASTAÑÓN, José Manuel. A responsabilidade penal do esportista: o exemplo do lutador de boxe. In: BEM, Leonardo Schmitt de; VICENTE MARTÍNEZ, Rosario de. Direito desportivo e conexões com o direito penal. São Paulo: Juruá, 2014, p. 431-446.

PAREKH, Bhikhi. Rethinking muticulturalism. Multicultural diversity and political theory. New York: Palgrave MacMilla, 2006.

PIERANGELI, José Henrique. Escritos jurídico-penais. São Paulo: Revista dos Tribunais, $3^{\mathrm{a}}$ ed., 2006. 
$3^{\mathrm{a}}$ ed., 2001.

O consentimento do ofendido na teoria do delito. São Paulo: Revista dos Tribunais,

PIRES, Álvaro. Amostragem e pesquisa qualitativa: ensaio teórico e metodológico. $A$ pesquisa qualitativa: enfoques epistemológicos e metodológicos. Petrópolis: Vozes, 2008, p. 154-211.

PORTILLA CONTRERAS, Guillermo. Tratamiento dogmático-penal de los supuestos de puesta en peligro imprudente por un tercero con aceptación por la víctima de la situación de riesgo. Cuadernos de política criminal, Madrid, nº 45, 1991.

PRADO, Luiz Regis. Bem jurídico-penal e Constituição. São Paulo: Revista dos Tribunais, $2^{\mathrm{a}}$ ed., 1997.

. Curso de direito penal brasileiro. Parte geral. São Paulo: Revista dos Tribunais, 2010, vol. 1.

; CARVALHO, Érika Mendes de. Teorias da imputação objetiva do resultado: uma aproximação crítica a seus fundamentos. São Paulo: Revista dos Tribunais, $1^{\mathrm{a}}$ ed., 2002. . Direito Penal do Ambiente. São Paulo: Revista dos Tribunais, 5ª ed., 2013.

PRESTES, Cássio Vinicius Del Castel Veronezzi Lazzari. O principio da insignificância como causa excludente da tipicidade no direito penal. São Paulo: Memória Jurídica, $1^{a}$ ed., 2003.

QUEIROZ, Rafael Mafei Rabelo. A modernização do direito penal brasileiro. São Paulo: Quatier Latin, 2007. . Monografia jurídica: passo a passo. São Paulo: Método, $1^{\text {a }}$ ed., 2015.

RASSI, João Daniel. Imputação das ações neutras e o dever de solidariedade no direito penal brasileira. Tese de Doutorado apresentada à Faculdade de Direito da Universidade de São Paulo (USP), 2012.

REALE JR., Miguel. Antijuridicidade concreta. São Paulo: José Bushatsky, 1973. . Instituições de Direito Penal: Parte Geral, vol. 1. Rio de Janeiro: Forense, $2^{\text {a }}$ edição, 2006.

Teoria do Delito. São Paulo: Revista dos Tribunais, $2^{\mathrm{a}}$ ed., 2000.

REIS, André Wagner Melgaço. O princípio da adequação social no direito penal. Revista de Estudos Criminais, Porto Alegre, v. 7, n. 27, out./dez. 2007, p. 217-223.

REIS, Carlos David Santos Aarão. Lesões corporais em esportes e direito à integridade física. Boletim dos Procuradores da República, São Paulo, v. 2, nº 15, jul. 1999, p. 3-4.

RIBEIRO DE FARIA, Maria Paula Bonifácio. A adequação social da conduta no direito penal ou o valor dos sentidos sociais na interpretação da lei penal. Porto, Ed. Universidade Católica, 1 $1^{\text {a }}$. ed., 2005.

RÍOS CORBACHO, José Manuel. Reflexões sobre o tratamento jurídico-penal das lesões no esporte. In: BEM, Leonardo Schmitt de; VICENTE MARTÍNEZ, Rosario de. Direito desportivo e conexões com o direito penal. São Paulo: Juruá, 2014, p. 447-466. 
ROBLES PLANAS, Ricardo. La participación en el delito: fundamentos y limites. Madrid: Marcial Pons, 2003.

RODRÍGUEZ MORO, Luis. El impacto del modelo social, económico y tecnológico de la sociedad actual en la tutela civil y penal de la propiedad intelectual. Revista de Derecho Penal: Fundación de Cultura Universitária, Montevideo, v. 21, 2ª́poca, dez. 2013, p. 93 110 .

ROLDÁN BARBERO, Horacio. Adecuación social y teoría jurídica del delito: sobre el contenido y los limites de una interpretación sociológica restrictiva de los tipos penales. Córdoba: Universidad de Córdoba, 1992.

ROSSATO, Luciano Alves; LÉPORE, Paulo Eduardo; CUNHA, Rogério Sanches. Estatuto da criança e do adolescente comentado artigo por artigo. São Paulo: Revista dos Tribunais, $6^{\mathrm{a}}$ ed., 2014.

ROTHBARTH, Guilherme Schmalz. A ocidentalização dos direitos humanos: a proibição da prática da mutilação genital feminina. Revista direitos humanos fundamentais, Osasco, v. 14, n. 1, jan./jun. 2014, p. 175-197.

ROXIN, Claus. Derecho penal. Parte general. Traducción y notas de Diego-Manuel Luzón Peña, Miguel Díaz y García Conlledo, Javier de Vicente Remesal. Madrid: Civitas, 1997.

. Finalismo: um balanço entre seus méritos e deficiências. Revista Brasileira de Ciências Criminais, São Paulo, v. 15, nº 65, mar./abr. 2007, p. 9-25.

- Observaciones sobre la adecuación social en el derecho penal. Cuadernos de doctrina y jurisprudencia penal, Buenos Aires, v. 7, n. 12, 2001, p. 81-94.

. Teoría del tipo penal. Buenos Aires: Ediciones Delpama, 1979.

RUEDA MARTÍN, María Ángeles. Consideraciones acerca de la relevancia penal de las acciones cotidianas en la comisión de un hecho doloso. Revista Penal, Valencia, $\mathrm{n}^{\mathbf{0}}$ 9, 2002, p. 122-133.

. La adecuación social y el delito de detenciones ilegales: comentario a la STS de 16 de diciembre de 1997. Revista de Derecho Penal y Criminología: Espanha, Madrid, no 7 , jan. 2001, p. 443-474.

. La teoría de la adecuación social. In: HIRSCH, Hans Joachim; CEREZO MIR, José; DONNA, Edgardo Alberto (orgs.). Hans Welzel en el pensamiento penal de la modernidad: homenaje en el centenario del nacimiento de Hans Welzel. Buenos Aires: Rubinzal-Culzoni, 2005, p. 485-572.

SACHER, Mariana. Rasgos normativos en la teoría de la adecuación social de Welzel. In: HIRSCH, Hans Joachim; CEREZO MIR, José; DONNA, Edgardo Alberto (orgs.). Hans Welzel en el pensamiento penal de la modernidad: homenaje en el centenario del nacimiento de Hans Welzel. Buenos Aires: Rubinzal-Culzoni, 2005, p. 573-596.

SALVADOR NETTO, Alamiro Velludo. Tipicidade penal e sociedade de risco. São Paulo: Quartier Latin, $1^{a}$ ed., 2006.

. Direito penal e propriedade privada. A racionalidade do sistema penal na tutela do patrimônio. São Paulo: Atlas, 2014 
SANTOS, Hugo Luz dos. O crime de branqueamento de capitais e o crime precedentes em Macau e em Portugal: concurso efectivo? Adequação social e exclusão da tipicidade? Revista do Ministério Público de Lisboa, Lisboa, v. 36, n 143, jul./set. 2015, p.79-104.

SILVA, Ivan Luiz da. Teoria da adequação econômica da conduta: o significado econômico da conduta em face da tutela penal antitruste. Tese de Doutorado apresentada à Universidade Federal de Pernambuco, 2009.

SILVA, Virgílio Afonso da. Direitos fundamentais: conteúdo essencial, restrições e eficácia. São Paulo: Malheiros, 2008.

SILVEIRA, Renato de Mello Jorge. Fundamentos da adequação social em direito penal. São Paulo: Quatier Latin, $1^{a}$ ed., 2010.

. Adequação social e Direito Penal. MENDES, Gilmar Ferreira; BOTTINI, Pierpaolo

Cruz; PACELLI, Eugenio (orgs.). Direito penal contemporâneo: questões controvertidas. São Paulo: Saraiva, 2011, p. 57-82.

. Crimes sexuais: bases críticas para a reforma do direito penal sexual. São Paulo: Quartier Latin, 2008.

THEODORO, Marcelo Antônio. A constituição como um sistema de princípios e regras. Revista de Direito Constitucional e Internacional: Cadernos de direito constitucional e ciência política, São Paulo, v. 16, n. 65, out./dez. 2008, p. 179-191.

TOLEDO, Francisco de Assis. Princípios básicos de direito penal. São Paulo: Saraiva, $5^{\text {a }}$ ed., 2000.

TULLY, James. Strange multiplicity: constitucionalism in an age of diversity. New York: Cambridge University Press, 1995.

VICO MANÃS, Carlos. Tipicidade e princípio da insignificância. Dissertação de Mestrado apresentada à Faculdade de Direito da Universidade de São Paulo, 1993.

WELZEL, Hans. A dogmática no direito penal. Revista de Direito Penal, 13/14, jan./jun. 1974, p. 7-12.

. Estudios de derecho penal. Tradução de Gustavo Eduardo Aboso e Tea Löw. Buenos Aires: Julio Cesar Faria 2003.

- O novo sistema jurídico-penal. Uma introdução à doutrina da ação finalista. Tradução, prefácio e notas de Luiz Regis Prado. São Paulo: Revista dos Tribunais, 2001.

. Derecho penal aleman. Santiago: Editoral Juridica e Chile, $4^{a}$ ed., 1997.

Derecho Penal: Parte General. Trad. Carlos Fontán Balestra. Buenos Aires: Roque Depalma Editor, 1956.

YACOBUCCI, Guillermo J. El sentido de los princípios penales. Su natureza y funciones em la argumentación penal. Buenos Aires: Ábaco de Rodolfo Depalma, 2002.

ZAFFARONI, Eugenio Raúl. Apuntes sobre el pensamiento penal en el tiempo. Buenos Aires, Hammurabi, 2007.

. La adecuación social de la conducta. Revista de Derecho Penal y Criminología: Argentina, n. 1, 1971, p. 71-79. 
; SLOKAR, Alejandro; ALAGLIA, Alejandro. Derecho Penal: Parte General. Buenos Aires: Ediar, $2^{\mathrm{a}}$ ed., 2002.

ZIPF, Heinz. Introducción a la política criminal. Madrid: Revista de Derecho Privado/Editoriales de Derecho Reunidas, 1979.

; MAURACH, Reinhart. Derecho Penal: Parte general 1. Traducción de Jorge Bofill Genzsch y Enrique Aimone Gobson. Buenos Aires: Astrea, 1994. 


\section{APÊNDICES}

\section{Apêndice A - Pesquisa quantitativa: formulário para a coleta de dados dos acórdãos do TJSP}

\section{DADOS SOBRE O PROCESSO:}

1. Número do acórdão:

2. Apelante:

3. Apelado:

4. Câmara Criminal:

5. Desembargador relator:

6. Data do julgamento:

7. Votação unânime:

$$
\begin{aligned}
& \text { ( ) Sim } \\
& \text { ( ) Não }
\end{aligned}
$$

8. Comarca de origem:

9. Crime:

10. Capitulação jurídica:

11. Decisão de primeiro grau:

( ) Condenação

( ) Absolvição

( ) Condenação por um(ns) crime(s) e absolvição por outro(s)

12. Caso haja absolvição, a teoria da adequação social foi invocada como fundamento?

( ) Sim

( ) Não

13. Nas razões recursais, a teoria adequação social foi invocada?

$$
\begin{aligned}
& \text { ( ) Sim } \\
& \text { ( ) Não }
\end{aligned}
$$

14. Houve discussão sobre a teoria da adequação social no acórdão?

( ) Sim

( ) Não

15. Decisão de segundo grau: 
( ) Houve reforma da sentença para condenar

( ) Houve reforma da sentença para absolver

( ) Houve reforma da sentença apenas para alterar a pena, o regime, ou para conceder ou negar benefícios

16. A adequação social foi usada como fundamento para a decisão?

( ) Sim. Especificar:

( ) Não 


\section{Apêndice B - Pesquisa qualitativa: formulário para a coleta de dados dos acórdãos do TJSP}

\section{DADOS SOBRE O PROCESSO:}

1. Número do acórdão:

2. Apelante:

3. Apelado:

4. Câmara Criminal:

5. Desembargador relator:

6. Data do julgamento:

7. Votação unânime:

( ) Sim

( ) Não

8. Comarca de origem:

9. Crime analisado:

( ) Violação de Direito Autoral

( ) Patrimonial. Especificar:

( ) Casa de prostituição

10. Capitulação jurídica:

11. Descrição do fato:

12. Adequação social invocada nas razões recursais?

( ) Sim

( ) Não

13. Se a resposta do item 12 for positiva, houve invocação de mais algum(a) princípio/teoria?

( ) Sim. Especificar:

( ) Não

14. Adequação social discutida no acórdão?

( ) Sim

( ) Não

15. Tratamento dado à adequação social:

( ) O magistrado não aceita a aplicação da teoria em nenhuma hipótese. Especificar o motivo: 
( ) O magistrado aceita a teoria, mas nega sua aplicação ao caso. Especificar o motivo:

( ) O magistrado aceita e aplica a teoria ao caso. Especificar o motivo:

16. Adequação social empregada na dosimetria da pena?

( ) Sim. Especificar:

( ) Não

17. Houve reforma da decisão de $1^{\circ}$ grau?

( ) Sim, total

( ) Sim, parcial

( ) Não

18. Se a resposta do item 17 for afirmativa, a adequação social constituiu o fundamento da reforma?

( ) Sim

( ） Não 
Apêndice C

Relação dos acórdãos utilizados na pesquisa quantitativa

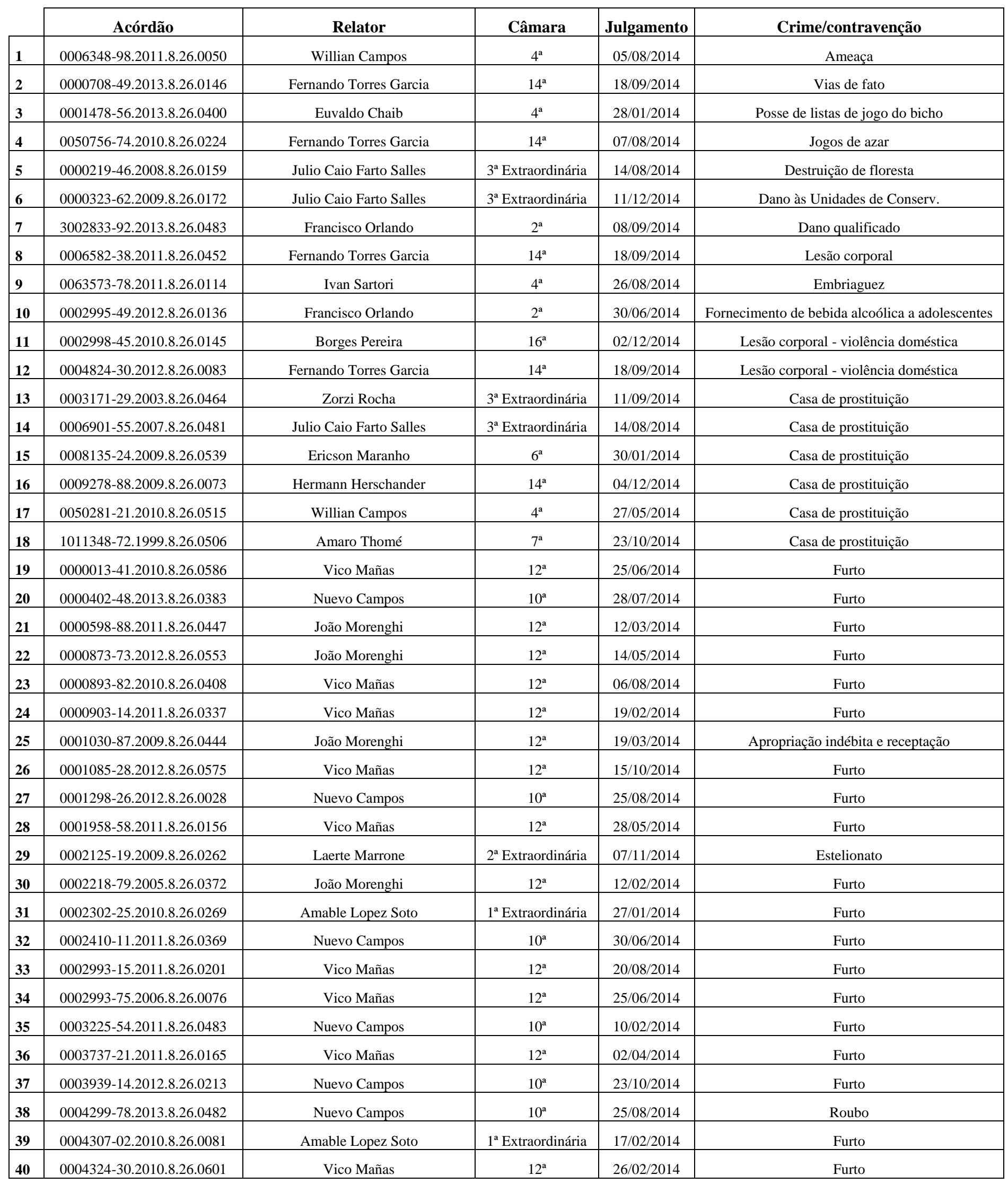




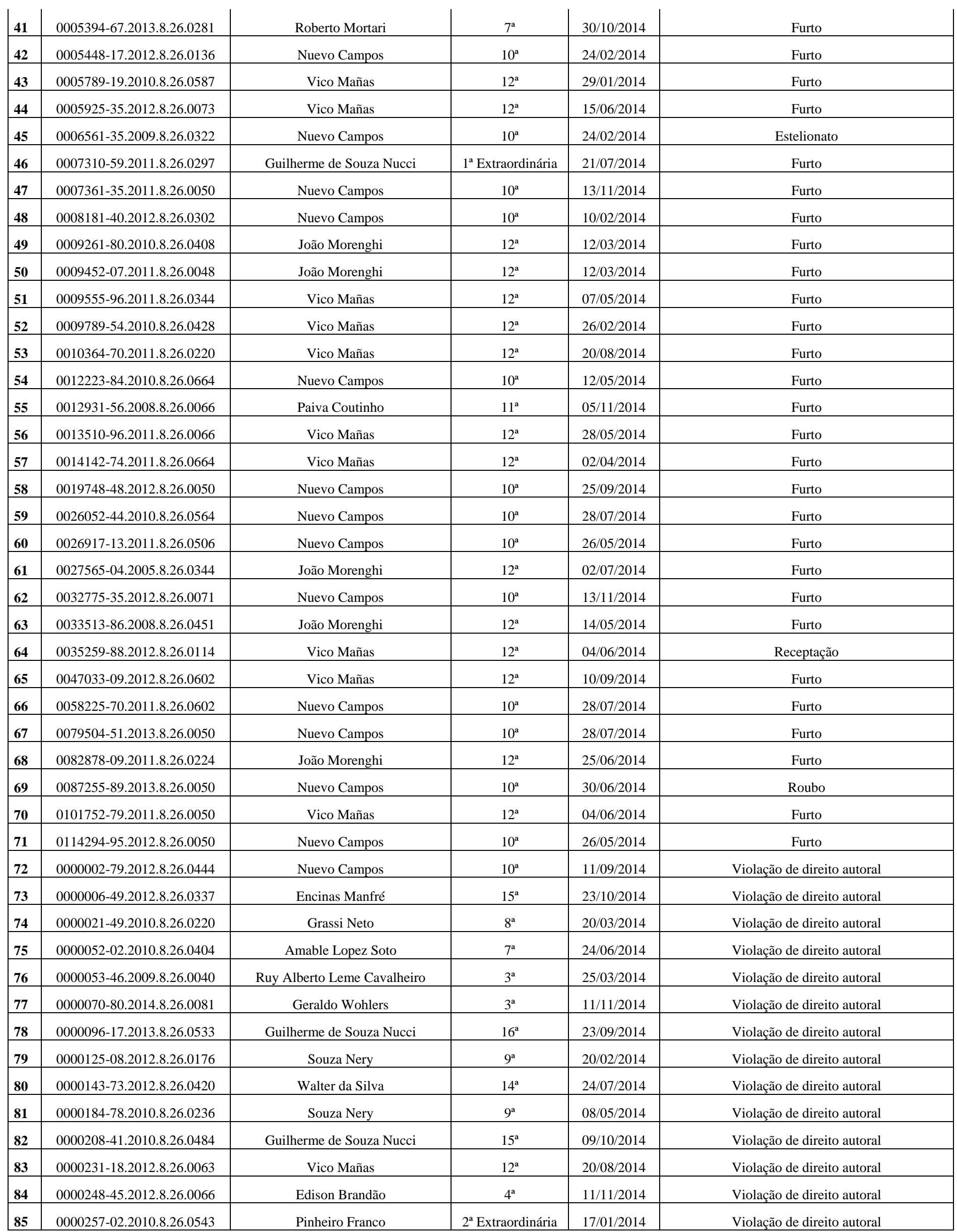




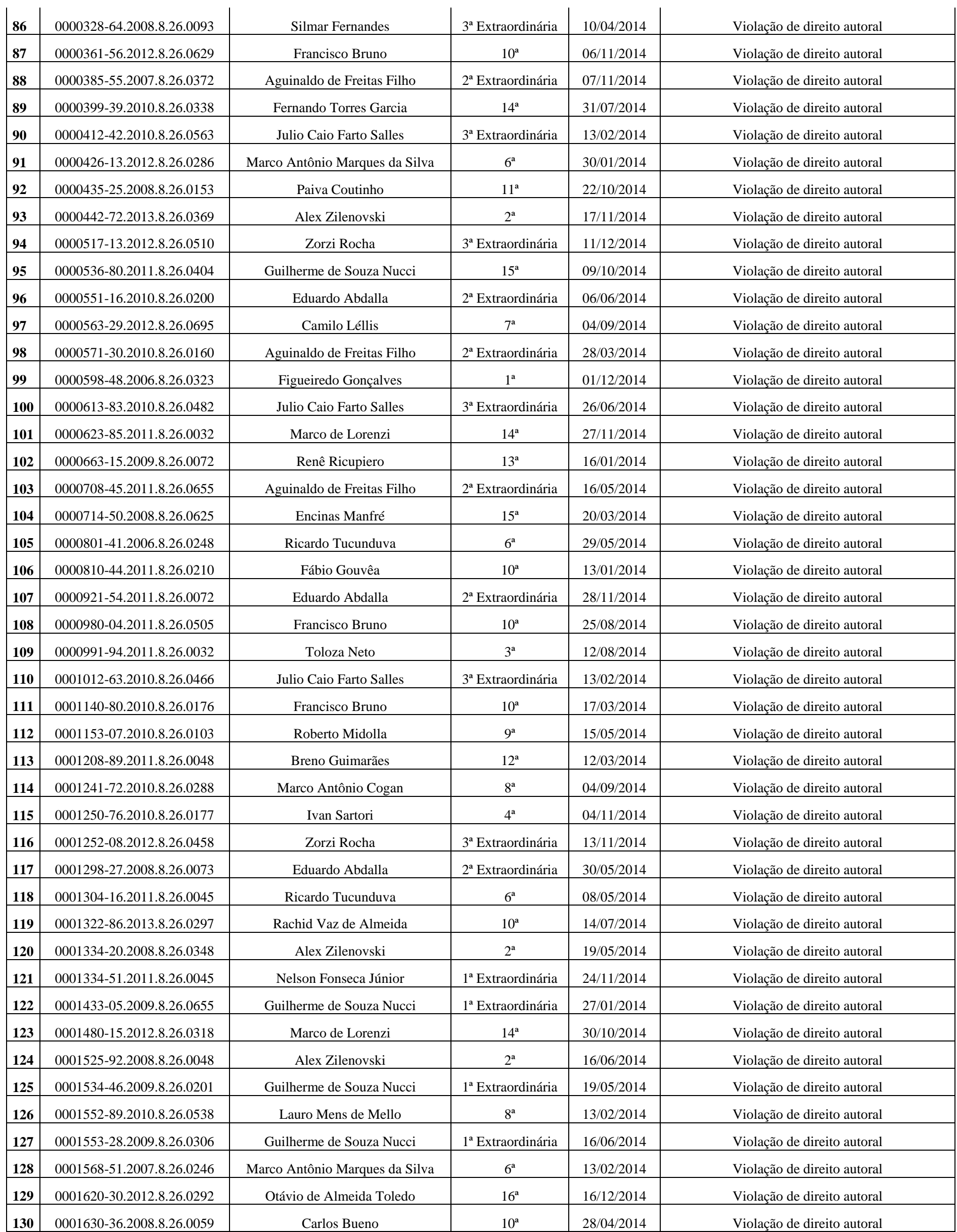




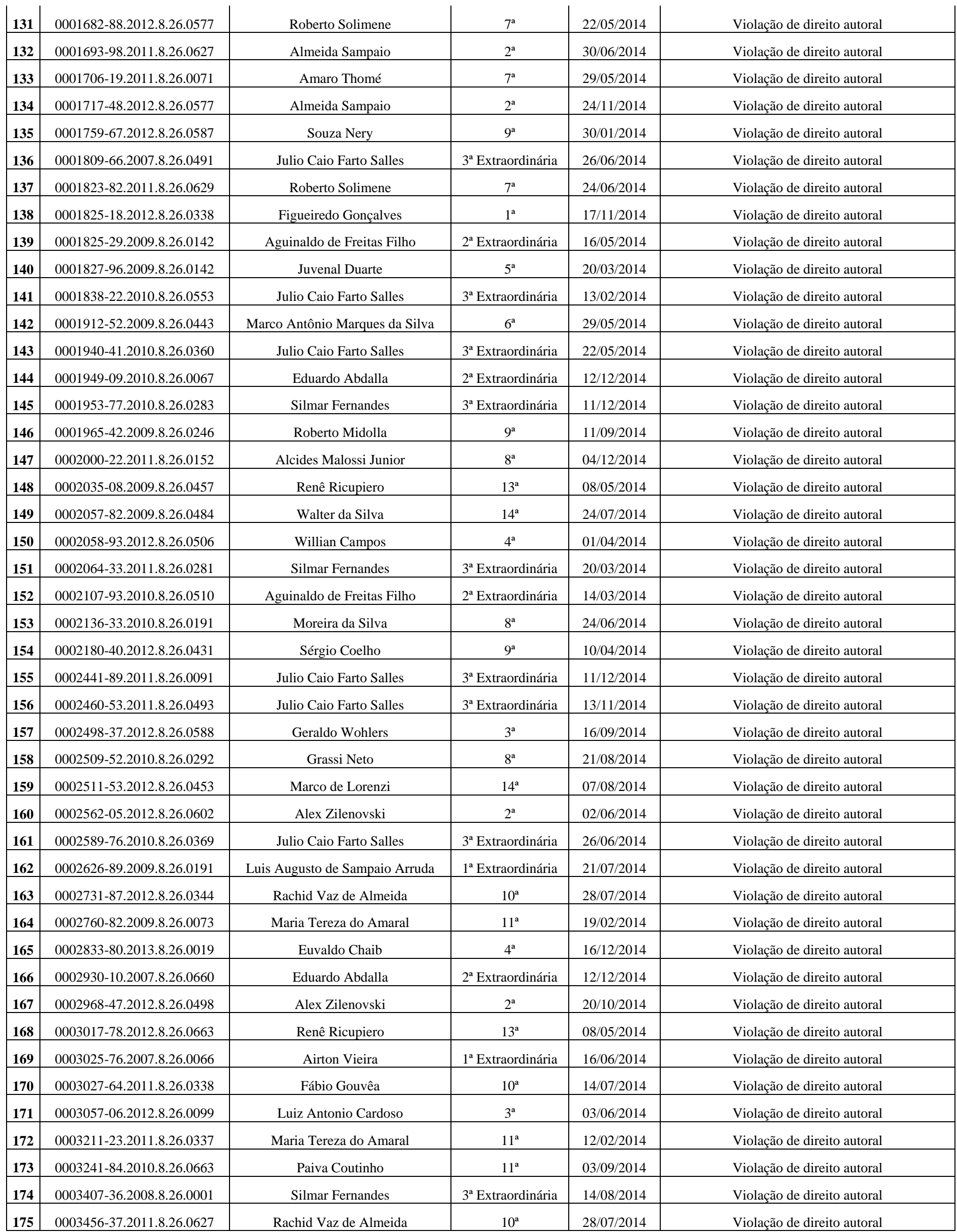




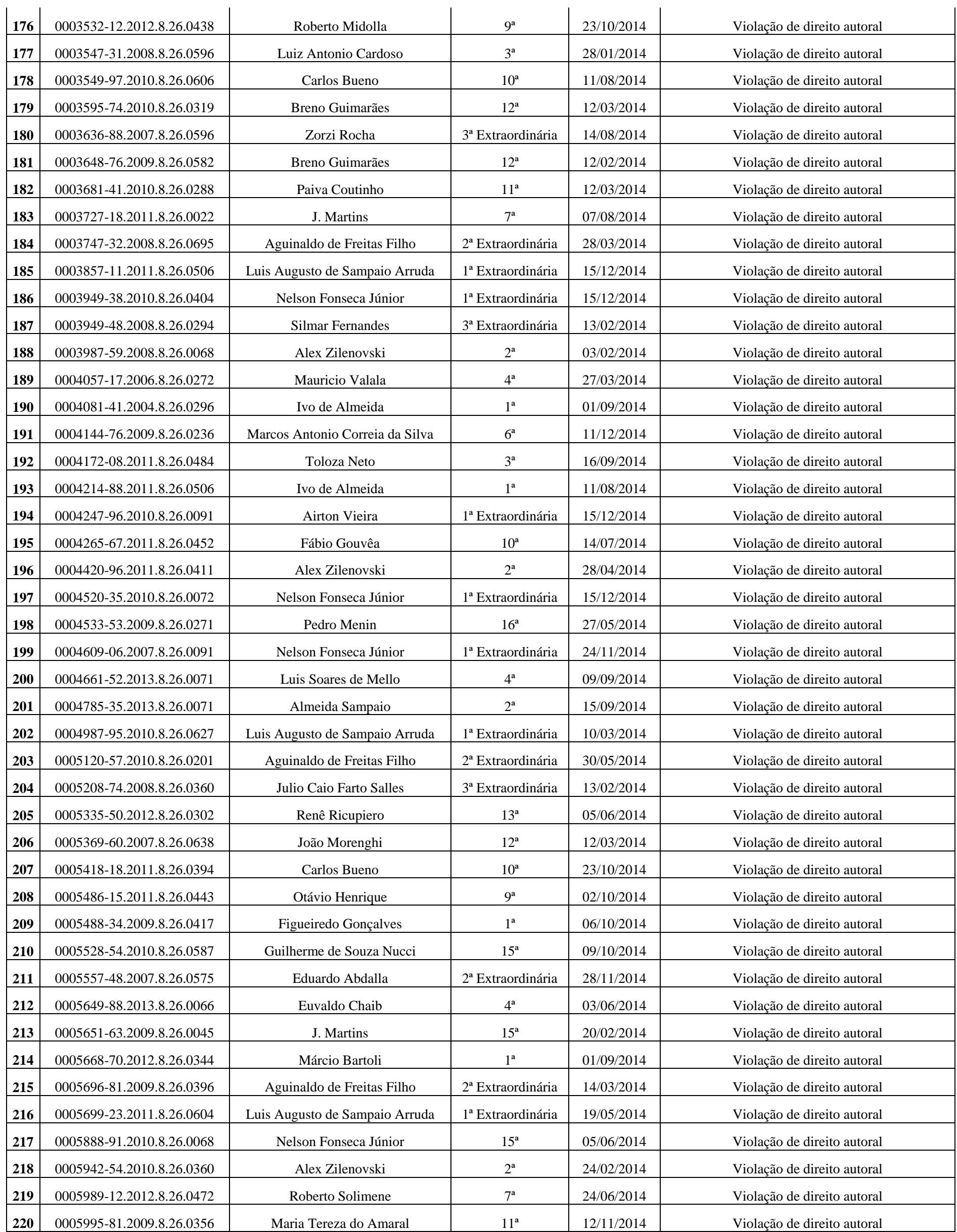




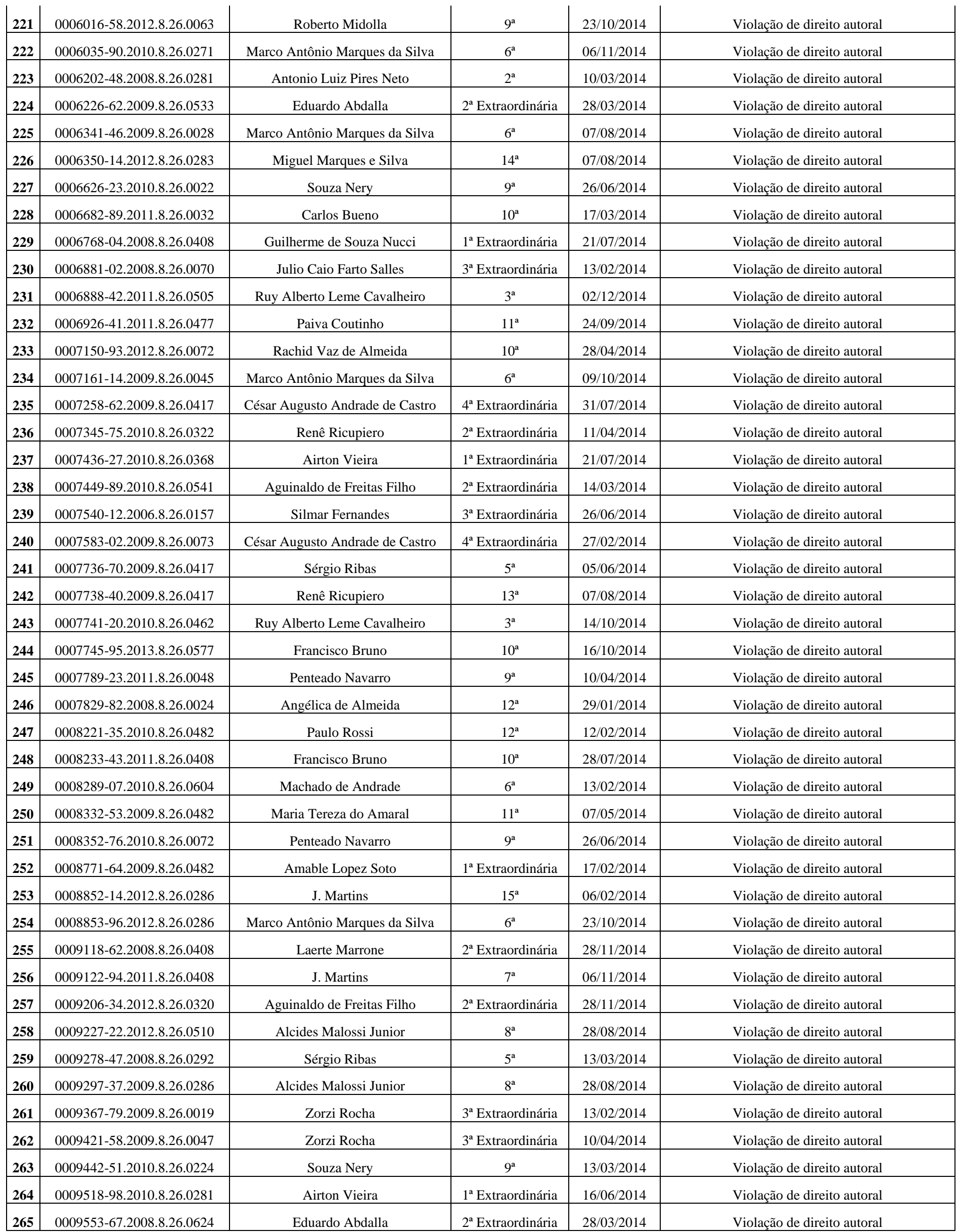




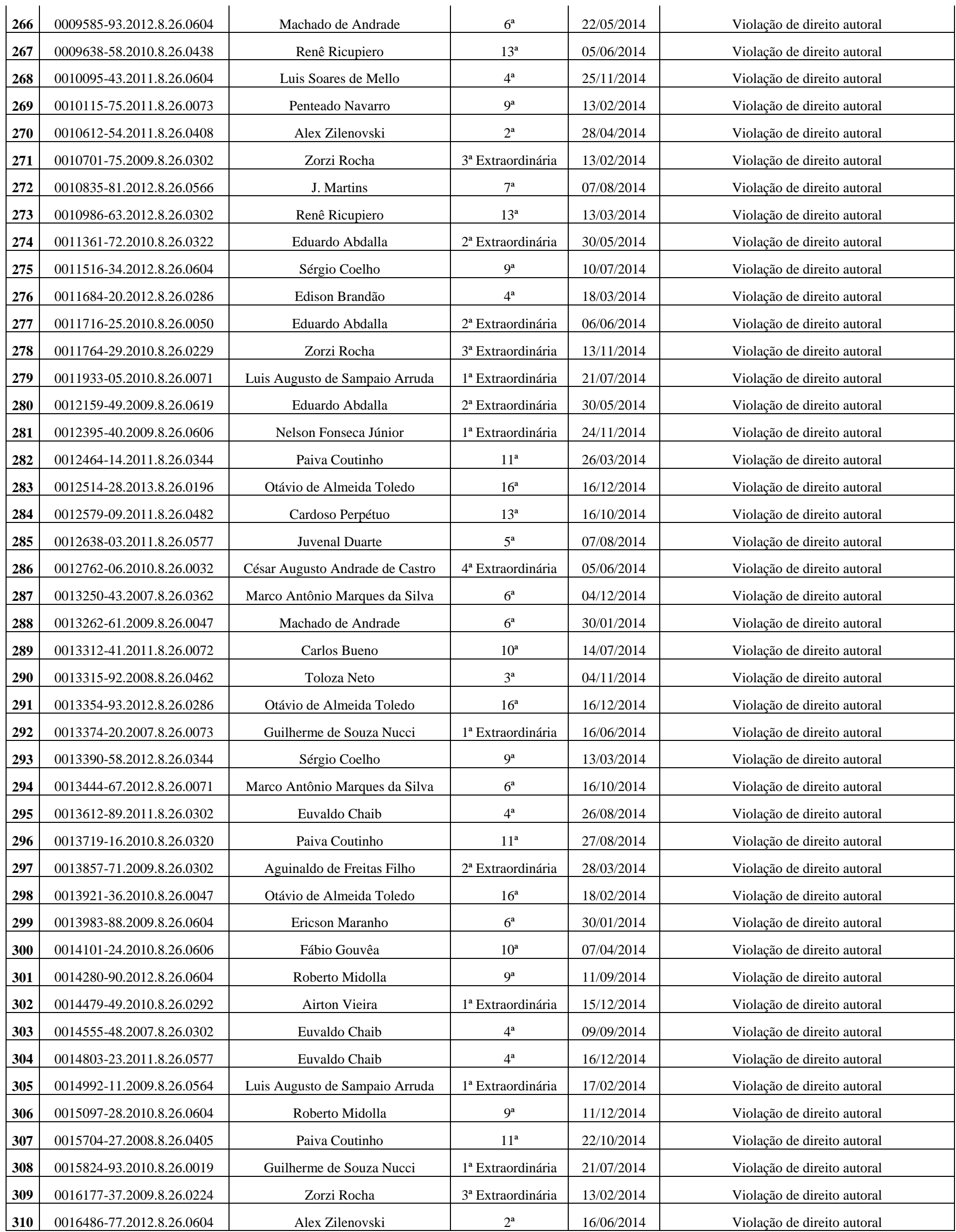




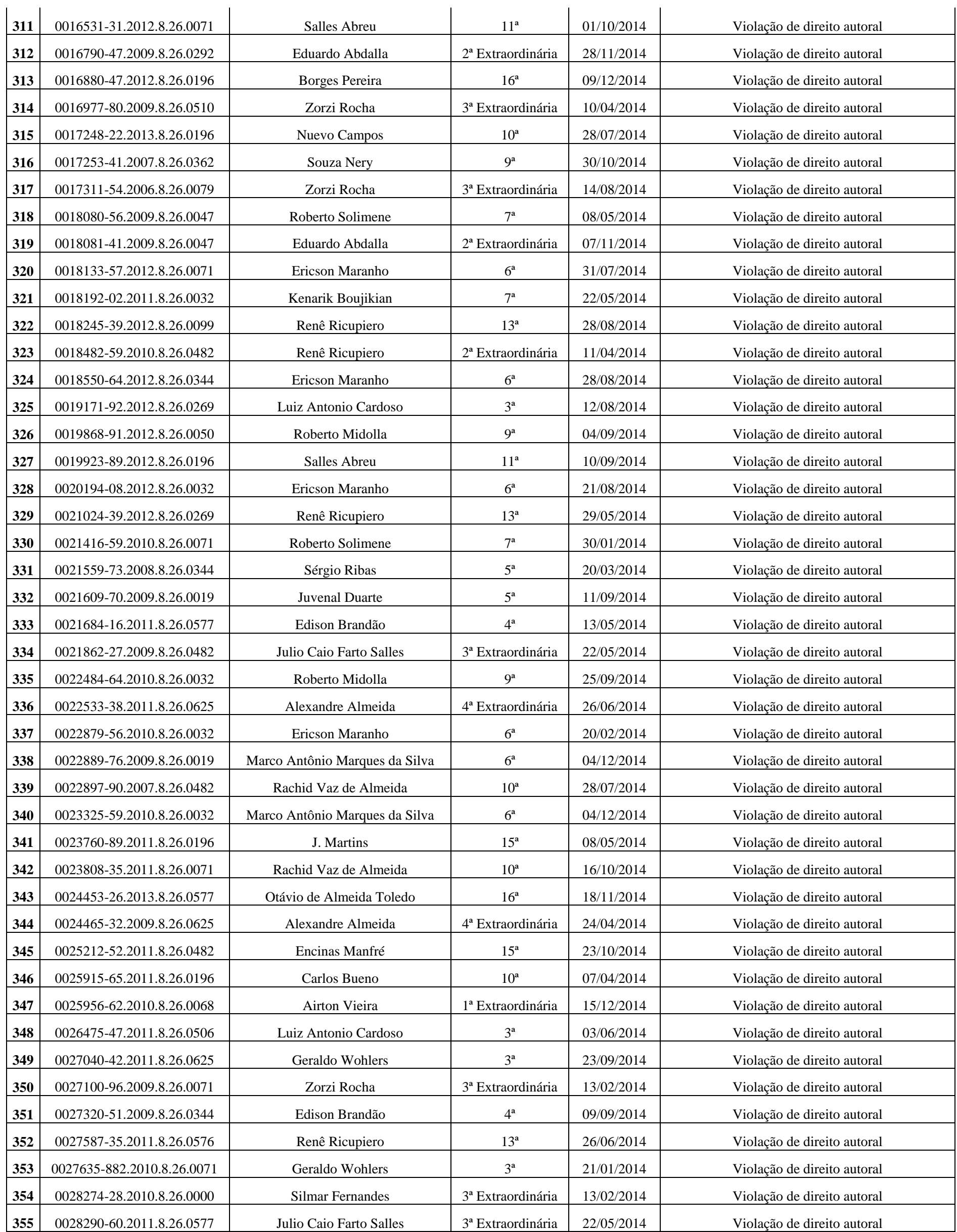




\begin{tabular}{|c|c|c|c|c|c|}
\hline 356 & 0029050-38.2012.8.26.0071 & Alex Zilenovski & $2^{\mathrm{a}}$ & $03 / 11 / 2014$ & Violação de direito autoral \\
\hline 358 & 0029758-90.2011.8.26.0114 & Pedro Menin & $16^{\mathrm{a}}$ & $27 / 05 / 2014$ & Violação de direito autoral \\
\hline 359 & 0029973-59.2008.8.26.0506 & Amaro Thomé & $7^{\mathrm{a}}$ & $23 / 10 / 2014$ & Violação de direito autoral \\
\hline 360 & 0030033-36.2010.8.26.0482 & Luiz Antonio Cardoso & $3^{\mathrm{a}}$ & $16 / 12 / 2014$ & Violação de direito autoral \\
\hline 361 & 0030135-58.2010.8.26.0482 & Renê Ricupiero & $13^{\mathrm{a}}$ & $25 / 09 / 2014$ & Violação de direito autoral \\
\hline 363 & 0031749-29.2010.8.26.0602 & Eduardo Abdalla & $2^{\mathrm{a}}$ Extraordinária & $28 / 03 / 2014$ & Violação de direito autoral \\
\hline 364 & 0035269-80.2012.8.26.0196 & Ricardo Tucunduva & $6^{\mathrm{a}}$ & $14 / 08 / 2014$ & Violação de direito autoral \\
\hline 365 & 0034750-29.2012.8.26.0577 & Luiz Antonio Cardoso & $3^{\mathrm{a}}$ & $11 / 11 / 2014$ & Violação de direito autoral \\
\hline 366 & 0036759-97.2009.8.26.0114 & Rachid Vaz de Almeida & $10^{\mathrm{a}}$ & $28 / 04 / 2014$ & Violação de direito autoral \\
\hline 370 & 0039583-61.2009.8.26.0071 & Luis Soares de Mello & $4^{\mathrm{a}}$ & $09 / 09 / 2014$ & Violação de direito autoral \\
\hline 371 & 0041052-37.2010.8.26.0224 & Ricardo Tucunduva & $6^{\mathrm{a}}$ & $11 / 12 / 2014$ & Violação de direito autoral \\
\hline 372 & 0042041-46.2011.8.26.0050 & Nuevo Campos & $10^{\mathrm{a}}$ & $26 / 05 / 2014$ & Violação de direito autoral \\
\hline 373 & 0042753-17.2009.8.26.0564 & Ruy Alberto Leme Cavalheiro & $3^{\mathrm{a}}$ & $21 / 01 / 2014$ & Violação de direito autoral \\
\hline 374 & 0044001-68.2009.8.26.0224 & Aguinaldo de Freitas Filho & $2^{\mathrm{a}}$ Extraordinária & $11 / 04 / 2014$ & Violação de direito autoral \\
\hline 375 & 0044083-39.2010.8.26.0071 & Miguel Marques e Silva & $14^{\mathrm{a}}$ & $24 / 07 / 2014$ & Violação de direito autoral \\
\hline 376 & 0044249-05.2011.8.26.0405 & Roberto Midolla & $9^{\mathrm{a}}$ & $11 / 12 / 2014$ & Violação de direito autoral \\
\hline 377 & 0046053-06.2012.8.26.0071 & Francisco Bruno & $10^{\mathrm{a}}$ & $25 / 09 / 2014$ & Violação de direito autoral \\
\hline 384 & 0049499-22.2008.8.26.0050 & Juvenal Duarte & $5^{\mathrm{a}}$ & $30 / 10 / 2014$ & Violação de direito autoral \\
\hline 385 & 0051647-61.2011.8.26.0224 & Alex Zilenovski & $2^{\mathrm{a}}$ & $02 / 06 / 2014$ & Violação de direito autoral \\
\hline 386 & 0052060-74.2011.8.26.0515 & Rachid Vaz de Almeida & $10^{\mathrm{a}}$ & $09 / 10 / 2014$ & Violação de direito autoral \\
\hline 387 & 0052388-09.2008.8.26.0224 & Silmar Fernandes & $3^{\mathrm{a}}$ Extraordinária & $09 / 10 / 2014$ & Violação de direito autoral \\
\hline 388 & 0052413-17.2011.8.26.0515 & Rachid Vaz de Almeida & $10^{\mathrm{a}}$ & $25 / 09 / 2014$ & Violação de direito autoral \\
\hline 389 & 0053160-10.2012.8.26.0651 & Guilherme G. Strenger & $11^{\mathrm{a}}$ & $25 / 06 / 2014$ & Violação de direito autoral \\
\hline 390 & 0054179-08.2011.8.26.0224 & Ivo de Almeida & $1^{\mathrm{a}}$ & 08/09/2014 & Violação de direito autoral \\
\hline 391 & 0058607-67.2010.8.26.0224 & Ruy Alberto Leme Cavalheiro & $3^{\mathrm{a}}$ & $12 / 08 / 2014$ & Violação de direito autoral \\
\hline 392 & 0058163-08.2011.8.26.0577 & Paiva Coutinho & $11^{\mathrm{a}}$ & $22 / 10 / 2014$ & Violação de direito autoral \\
\hline 393 & 0060453-30.2010.8.26.0577 & Silmar Fernandes & $3^{\text {a Extraordinária }}$ & 09/10/2014 & Violação de direito autoral \\
\hline 394 & 0061381-41.2012.8.26.0114 & Marco de Lorenzi & $14^{\mathrm{a}}$ & $20 / 03 / 2014$ & Violação de direito autoral \\
\hline 395 & 0062187-53.2009.8.26.0576 & Luis Augusto de Sampaio Arruda & $1^{\mathrm{a}}$ Extraordinária & $10 / 03 / 2014$ & Violação de direito autoral \\
\hline 396 & 0062895-63.2011.8.26.0114 & Amaro Thomé & $7^{\mathrm{a}}$ & 09/10/2014 & Violação de direito autoral \\
\hline 397 & 0064433-09.2007.8.26.0506 & Edison Brandão & $4^{\mathrm{a}}$ & $11 / 11 / 2014$ & Violação de direito autoral \\
\hline 398 & 0066590-54.2009.8.26.0224 & Julio Caio Farto Salles & $3^{\mathrm{a}}$ Extraordinária & $26 / 06 / 2014$ & Violação de direito autoral \\
\hline 399 & 0066749-60.2010.8.26.0224 & Grassi Neto & $8^{\mathrm{a}}$ & $28 / 08 / 2014$ & Violação de direito autoral \\
\hline 400 & 0066967-31.2012.8.26.0576 & Xavier de Souza & $11^{\mathrm{a}}$ & 06/08/2014 & Violação de direito autoral \\
\hline
\end{tabular}




\begin{tabular}{|c|c|c|c|c|c|}
\hline 401 & 0068148-61.2009.8.26.0224 & Airton Vieira & $1^{a}$ Extraordinária & $16 / 06 / 2014$ & Violação de direito autoral \\
\hline 403 & 0069244-14.2009.8.26.0224 & Paiva Coutinho & $11^{\mathrm{a}}$ & $22 / 10 / 2014$ & Violação de direito autoral \\
\hline 404 & 0071933-65.2008.8.26.0224 & Ricardo Tucunduva & $6^{\mathrm{a}}$ & 07/08/2014 & Violação de direito autoral \\
\hline 405 & 0078093-72.2009.8.26.0224 & Juvenal Duarte & $5^{\mathrm{a}}$ & $16 / 10 / 2014$ & Violação de direito autoral \\
\hline 406 & 0078267-13.2011.8.26.0224 & Renê Ricupiero & $13^{\mathrm{a}}$ & $05 / 06 / 2014$ & Violação de direito autoral \\
\hline 408 & 0079570-65.2012.8.26.0050 & Eduardo Abdalla & $2^{\mathrm{a}}$ Extraordinária & $12 / 12 / 2014$ & Violação de direito autoral \\
\hline 409 & 0089095-42.2010.8.26.0050 & Toloza Neto & $3^{\mathrm{a}}$ & $14 / 10 / 2014$ & Violação de direito autoral \\
\hline 410 & 0089247-87.2009.8.26.0224 & Luis Augusto de Sampaio Arruda & $1^{a}$ Extraordinária & $21 / 07 / 2014$ & Violação de direito autoral \\
\hline 411 & 0090216-08.2010.8.26.0050 & Nuevo Campos & $10^{\mathrm{a}}$ & 09/06/2014 & Violação de direito autoral \\
\hline 415 & 0399806-86.2010.8.26.0000 & Amaro Thomé & $7^{\mathrm{a}}$ & 03/07/2014 & Violação de direito autoral \\
\hline 416 & 0781270-11.2009.8.26.0577 & Edison Brandão & $4^{\mathrm{a}}$ & $25 / 11 / 2014$ & Violação de direito autoral \\
\hline 417 & 0964474-72.2012.8.26.0506 & Fábio Gouvêa & $10^{\mathrm{a}}$ & $06 / 11 / 2014$ & Violação de direito autoral \\
\hline 418 & $3000502-19.2008 .8 .26 .0482$ & Grassi Neto & $8^{\mathrm{a}}$ & 20/03/2014 & Violação de direito autoral \\
\hline 419 & $3001440-35.2013 .8 .26 .0483$ & Sérgio Coelho & $9^{\mathrm{a}}$ & $27 / 11 / 2014$ & Violação de direito autoral \\
\hline 420 & $9000002-45.2012 .8 .26 .0081$ & Fábio Gouvêa & $10^{\mathrm{a}}$ & $13 / 11 / 2014$ & Violação de direito autoral \\
\hline 421 & $9000002-05.2006 .8 .26 .0615$ & César Augusto Andrade de Castro & $4^{\mathrm{a}}$ Extraordinária & $26 / 06 / 2014$ & Violação de direito autoral \\
\hline 422 & 9000002-21.2006.8.26.0157 & Osni Pereira & $16^{\mathrm{a}}$ & $02 / 12 / 2014$ & Violação de direito autoral \\
\hline 429 & 9000114-44.2011.8.26.0050 & Machado de Andrade & $6^{\mathrm{a}}$ & $20 / 02 / 2014$ & Violação de direito autoral \\
\hline
\end{tabular}




\section{Apêndice D}

\section{Relação dos acórdãos utilizados na pesquisa qualitativa}

\begin{tabular}{|c|c|c|c|c|c|}
\hline & Acórdão & Relator & Câmara & Julgamento & Crime/contravenção \\
\hline 1 & 0006901-55.2007.8.26.0481 & Julio Caio Farto Salles & $3^{\mathrm{a}}$ Extraordinária & $14 / 08 / 2014$ & Casa de prostituição \\
\hline 2 & 0008135-24.2009.8.26.0539 & Ericson Maranho & $6^{\mathrm{a}}$ & $30 / 01 / 2014$ & Casa de prostituição \\
\hline 3 & 0009278-88.2009.8.26.0073 & Hermann Herschander & $14^{\mathrm{a}}$ & $04 / 12 / 2014$ & Casa de prostituição \\
\hline 4 & 0050281-21.2010.8.26.0515 & Willian Campos & $4^{\mathrm{a}}$ & $27 / 05 / 2014$ & Casa de prostituição \\
\hline 5 & 0000013-41.2010.8.26.0586 & Vico Mañas & $12^{\mathrm{a}}$ & $25 / 06 / 2014$ & Furto \\
\hline 6 & 0002125-19.2009.8.26.0262 & Laerte Marrone & $2^{\mathrm{a}}$ Extraordinária & $07 / 11 / 2014$ & Estelionato \\
\hline 7 & 0003939-14.2012.8.26.0213 & Nuevo Campos & $10^{\mathrm{a}}$ & $23 / 10 / 2014$ & Furto \\
\hline 8 & 0004299-78.2013.8.26.0482 & Nuevo Campos & $10^{\mathrm{a}}$ & $25 / 08 / 2014$ & Roubo \\
\hline 9 & 0005394-67.2013.8.26.0281 & Roberto Mortari & $7^{\mathrm{a}}$ & $30 / 10 / 2014$ & Furto \\
\hline 10 & 0006561-35.2009.8.26.0322 & Nuevo Campos & $10^{\mathrm{a}}$ & $24 / 02 / 2014$ & Estelionato \\
\hline 11 & 0007361-35.2011.8.26.0050 & Nuevo Campos & $10^{\mathrm{a}}$ & $13 / 11 / 2014$ & Furto \\
\hline 12 & 0012931-56.2008.8.26.0066 & Paiva Coutinho & $11^{\mathrm{a}}$ & $05 / 11 / 2014$ & Furto \\
\hline 13 & $0000002-79.2012 .8 .26 .0444$ & Nuevo Campos & $10^{\mathrm{a}}$ & $11 / 09 / 2014$ & Violação de direito autoral \\
\hline 14 & 0000006-49.2012.8.26.0337 & Encinas Manfré & $15^{\mathrm{a}}$ & $23 / 10 / 2014$ & Violação de direito autoral \\
\hline 15 & 0000021-49.2010.8.26.0220 & Grassi Neto & $8^{\mathrm{a}}$ & $20 / 03 / 2014$ & Violação de direito autoral \\
\hline 16 & 0000052-02.2010.8.26.0404 & Amable Lopez Soto & $7^{\mathrm{a}}$ & $24 / 06 / 2014$ & Violação de direito autoral \\
\hline 17 & 0000053-46.2009.8.26.0040 & Ruy Alberto Leme Cavalheiro & $3^{\mathrm{a}}$ & $25 / 03 / 2014$ & Violação de direito autoral \\
\hline 18 & 0000070-80.2014.8.26.0081 & Geraldo Wohlers & $3^{\mathrm{a}}$ & $11 / 11 / 2014$ & Violação de direito autoral \\
\hline 19 & 0000096-17.2013.8.26.0533 & Guilherme de Souza Nucci & $16^{\mathrm{a}}$ & $23 / 09 / 2014$ & Violação de direito autoral \\
\hline 20 & 0000125-08.2012.8.26.0176 & Souza Nery & $9^{a}$ & $20 / 02 / 2014$ & Violação de direito autoral \\
\hline 21 & $0000248-45.2012 .8 .26 .0066$ & Edison Brandão & $4^{\mathrm{a}}$ & $11 / 11 / 2014$ & Violação de direito autoral \\
\hline 22 & 0000361-56.2012.8.26.0629 & Francisco Bruno & $10^{\mathrm{a}}$ & $06 / 11 / 2014$ & Violação de direito autoral \\
\hline 23 & 0000412-42.2010.8.26.0563 & Julio Caio Farto Salles & $3^{\mathrm{a}}$ Extraordinária & $13 / 02 / 2014$ & Violação de direito autoral \\
\hline 24 & 0000435-25.2008.8.26.0153 & Paiva Coutinho & $11^{\mathrm{a}}$ & $22 / 10 / 2014$ & Violação de direito autoral \\
\hline 25 & 0000442-72.2013.8.26.0369 & Alex Zilenovski & $2^{\mathrm{a}}$ & $17 / 11 / 2014$ & Violação de direito autoral \\
\hline 26 & $0000517-13.2012 .8 .26 .0510$ & Zorzi Rocha & $3^{\mathrm{a}}$ Extraordinária & $11 / 12 / 2014$ & Violação de direito autoral \\
\hline 27 & 0000563-29.2012.8.26.0695 & Camilo Léllis & $7^{\mathrm{a}}$ & $04 / 09 / 2014$ & Violação de direito autoral \\
\hline 28 & 0000663-15.2009.8.26.0072 & Renê Ricupiero & $13^{\mathrm{a}}$ & $16 / 01 / 2014$ & Violação de direito autoral \\
\hline 29 & 0000801-41.2006.8.26.0248 & Ricardo Tucunduva & $6^{\mathrm{a}}$ & $29 / 05 / 2014$ & Violação de direito autoral \\
\hline 30 & 0000810-44.2011.8.26.0210 & Fábio Gouvêa & $10^{\mathrm{a}}$ & $13 / 01 / 2014$ & Violação de direito autoral \\
\hline 31 & 0000991-94.2011.8.26.0032 & Toloza Neto & $3^{\mathrm{a}}$ & $12 / 08 / 2014$ & Violação de direito autoral \\
\hline 32 & 0001153-07.2010.8.26.0103 & Roberto Midolla & $9^{\mathrm{a}}$ & $15 / 05 / 2014$ & Violação de direito autoral \\
\hline 33 & 0001241-72.2010.8.26.0288 & Marco Antônio Cogan & $8^{\mathrm{a}}$ & $04 / 09 / 2014$ & Violação de direito autoral \\
\hline 34 & 0001322-86.2013.8.26.0297 & Rachid Vaz de Almeida & $10^{\mathrm{a}}$ & $14 / 07 / 2014$ & Violação de direito autoral \\
\hline 35 & 0001334-51.2011.8.26.0045 & Nelson Fonseca Júnior & $1^{\mathrm{a}}$ Extraordinária & $24 / 11 / 2014$ & Violação de direito autoral \\
\hline 36 & 0001620-30.2012.8.26.0292 & Otávio de Almeida Toledo & $16^{\mathrm{a}}$ & $16 / 12 / 2014$ & Violação de direito autoral \\
\hline 37 & 0001630-36.2008.8.26.0059 & Carlos Bueno & $10^{\mathrm{a}}$ & $28 / 04 / 2014$ & Violação de direito autoral \\
\hline 38 & 0001682-88.2012.8.26.0577 & Roberto Solimene & $7^{\mathrm{a}}$ & $22 / 05 / 2014$ & Violação de direito autoral \\
\hline 39 & 0001809-66.2007.8.26.0491 & Julio Caio Farto Salles & $3^{\mathrm{a}}$ Extraordinária & $26 / 06 / 2014$ & Violação de direito autoral \\
\hline
\end{tabular}




\begin{tabular}{|c|c|c|c|c|c|}
\hline 40 & $0001827-96.2009 .8 .26 .0142$ & Juvenal Duarte & $5^{\mathrm{a}}$ & $20 / 03 / 2014$ & Violação de direito autoral \\
\hline 41 & 0002000-22.2011.8.26.0152 & Alcides Malossi Junior & $8^{\mathrm{a}}$ & $04 / 12 / 2014$ & Violação de direito autoral \\
\hline 42 & 0002035-08.2009.8.26.0457 & Renê Ricupiero & $13^{\mathrm{a}}$ & $08 / 05 / 2014$ & Violação de direito autoral \\
\hline 43 & 0002136-33.2010.8.26.0191 & Moreira da Silva & $8^{\mathrm{a}}$ & $24 / 06 / 2014$ & Violação de direito autoral \\
\hline 44 & $0002180-40.2012 .8 .26 .0431$ & Sérgio Coelho & $9^{\mathrm{a}}$ & $10 / 04 / 2014$ & Violação de direito autoral \\
\hline 45 & 0002441-89.2011.8.26.0091 & Julio Caio Farto Salles & $3^{\mathrm{a}}$ Extraordinária & $11 / 12 / 2014$ & Violação de direito autoral \\
\hline 46 & 0002626-89.2009.8.26.0191 & Luis Augusto de Sampaio Arruda & $1^{\mathrm{a}}$ Extraordinária & $21 / 07 / 2014$ & Violação de direito autoral \\
\hline 47 & 0002731-87.2012.8.26.0344 & Rachid Vaz de Almeida & $10^{\mathrm{a}}$ & $28 / 07 / 2014$ & Violação de direito autoral \\
\hline 48 & $0003025-76.2007 .8 .26 .0066$ & Airton Vieira & $1^{\text {a }}$ Extraordinária & $16 / 06 / 2014$ & Violação de direito autoral \\
\hline 49 & 0003057-06.2012.8.26.0099 & Luiz Antonio Cardoso & $3^{\mathrm{a}}$ & $03 / 06 / 2014$ & Violação de direito autoral \\
\hline $\mathbf{5 0}$ & $0003241-84.2010 .8 .26 .0663$ & Paiva Coutinho & $11^{\mathrm{a}}$ & $03 / 09 / 2014$ & Violação de direito autoral \\
\hline 51 & 0003456-37.2011.8.26.0627 & Rachid Vaz de Almeida & $10^{\mathrm{a}}$ & $28 / 07 / 2014$ & Violação de direito autoral \\
\hline 52 & 0003857-11.2011.8.26.0506 & Luis Augusto de Sampaio Arruda & $1^{\mathrm{a}}$ Extraordinária & $15 / 12 / 2014$ & Violação de direito autoral \\
\hline 53 & 0003949-38.2010.8.26.0404 & Nelson Fonseca Júnior & $1^{\text {a }}$ Extraordinária & $15 / 12 / 2014$ & Violação de direito autoral \\
\hline 54 & 0004144-76.2009.8.26.0236 & Marcos Antonio Correia da Silva & $6^{\mathrm{a}}$ & $11 / 12 / 2014$ & Violação de direito autoral \\
\hline 55 & 0004247-96.2010.8.26.0091 & Airton Vieira & $1^{\mathrm{a}}$ Extraordinária & $15 / 12 / 2014$ & Violação de direito autoral \\
\hline 56 & $0004661-52.2013 .8 .26 .0071$ & Luis Soares de Mello & $4^{\mathrm{a}}$ & $09 / 09 / 2014$ & Violação de direito autoral \\
\hline 57 & 0004785-35.2013.8.26.0071 & Almeida Sampaio & $2^{\mathrm{a}}$ & $15 / 09 / 2014$ & Violação de direito autoral \\
\hline 58 & 0005369-60.2007.8.26.0638 & João Morenghi & $12^{\mathrm{a}}$ & $12 / 03 / 2014$ & Violação de direito autoral \\
\hline 59 & $0005486-15.2011 .8 .26 .0443$ & Otávio Henrique & $9^{\mathrm{a}}$ & $02 / 10 / 2014$ & Violação de direito autoral \\
\hline 60 & 0005488-34.2009.8.26.0417 & Figueiredo Gonçalves & $1^{\mathrm{a}}$ & $06 / 10 / 2014$ & Violação de direito autoral \\
\hline 61 & 0005649-88.2013.8.26.0066 & Euvaldo Chaib & $4^{\mathrm{a}}$ & $03 / 06 / 2014$ & Violação de direito autoral \\
\hline 62 & 0005651-63.2009.8.26.0045 & J. Martins & $15^{\mathrm{a}}$ & $20 / 02 / 2014$ & Violação de direito autoral \\
\hline 63 & $0005668-70.2012 .8 .26 .0344$ & Márcio Bartoli & $1^{\mathrm{a}}$ & $01 / 09 / 2014$ & Violação de direito autoral \\
\hline 64 & $0005696-81.2009 .8 .26 .0396$ & Aguinaldo de Freitas Filho & $2^{\text {a }}$ Extraordinária & $14 / 03 / 2014$ & Violação de direito autoral \\
\hline 65 & 0005995-81.2009.8.26.0356 & Maria Tereza do Amaral & $11^{\mathrm{a}}$ & $12 / 11 / 2014$ & Violação de direito autoral \\
\hline 66 & $0006035-90.2010 .8 .26 .0271$ & Marco Antônio Marques da Silva & $6^{\mathrm{a}}$ & $06 / 11 / 2014$ & Violação de direito autoral \\
\hline 67 & $0006202-48.2008 .8 .26 .0281$ & Antonio Luiz Pires Neto & $2^{\mathrm{a}}$ & $10 / 03 / 2014$ & Violação de direito autoral \\
\hline 68 & $0006226-62.2009 .8 .26 .0533$ & Eduardo Abdalla & $2^{\mathrm{a}}$ Extraordinária & $28 / 03 / 2014$ & Violação de direito autoral \\
\hline 69 & $0007540-12.2006 .8 .26 .0157$ & Silmar Fernandes & $3^{\mathrm{a}}$ Extraordinária & $26 / 06 / 2014$ & Violação de direito autoral \\
\hline 70 & 0007736-70.2009.8.26.0417 & Sérgio Ribas & $5^{\mathrm{a}}$ & $05 / 06 / 2014$ & Violação de direito autoral \\
\hline 71 & $0008233-43.2011 .8 .26 .0408$ & Francisco Bruno & $10^{\mathrm{a}}$ & $28 / 07 / 2014$ & Violação de direito autoral \\
\hline 72 & 0009118-62.2008.8.26.0408 & Laerte Marrone & $2^{\mathrm{a}}$ Extraordinária & $28 / 11 / 2014$ & Violação de direito autoral \\
\hline 73 & 0009367-79.2009.8.26.0019 & Zorzi Rocha & $3^{\mathrm{a}}$ Extraordinária & $13 / 02 / 2014$ & Violação de direito autoral \\
\hline 74 & 0009442-51.2010.8.26.0224 & Souza Nery & $9^{a}$ & $13 / 03 / 2014$ & Violação de direito autoral \\
\hline 75 & 0010095-43.2011.8.26.0604 & Luis Soares de Mello & $4^{\mathrm{a}}$ & $25 / 11 / 2014$ & Violação de direito autoral \\
\hline 76 & 0010115-75.2011.8.26.0073 & Penteado Navarro & $9^{a}$ & $13 / 02 / 2014$ & Violação de direito autoral \\
\hline 77 & 0012579-09.2011.8.26.0482 & Cardoso Perpétuo & $13^{\mathrm{a}}$ & $16 / 10 / 2014$ & Violação de direito autoral \\
\hline 78 & 0013262-61.2009.8.26.0047 & Machado de Andrade & $6^{\mathrm{a}}$ & $30 / 01 / 2014$ & Violação de direito autoral \\
\hline 79 & $0013315-92.2008 .8 .26 .0462$ & Toloza Neto & $3^{\mathrm{a}}$ & $04 / 11 / 2014$ & Violação de direito autoral \\
\hline 80 & 0013983-88.2009.8.26.0604 & Ericson Maranho & $6^{\mathrm{a}}$ & $30 / 01 / 2014$ & Violação de direito autoral \\
\hline 81 & 0014479-49.2010.8.26.0292 & Airton Vieira & $1^{\mathrm{a}}$ Extraordinária & $15 / 12 / 2014$ & Violação de direito autoral \\
\hline 82 & $0018080-56.2009 .8 .26 .0047$ & Roberto Solimene & $7^{\mathrm{a}}$ & $08 / 05 / 2014$ & Violação de direito autoral \\
\hline 83 & $0022533-38.2011 .8 .26 .0625$ & Alexandre Almeida & $4^{\mathrm{a}}$ Extraordinária & $26 / 06 / 2014$ & Violação de direito autoral \\
\hline 84 & $0025212-52.2011 .8 .26 .0482$ & Encinas Manfré & $15^{\mathrm{a}}$ & $23 / 10 / 2014$ & Violação de direito autoral \\
\hline
\end{tabular}




\begin{tabular}{|l|c|c|c|c|c|}
$\mathbf{8 5}$ & $0029758-90.2011 .8 .26 .0114$ & Pedro Menin & $16^{\mathrm{a}}$ & $27 / 05 / 2014$ & Violação de direito autoral \\
\hline $\mathbf{8 6}$ & $0029973-59.2008 .8 .26 .0506$ & Amaro Thomé & $7^{\mathrm{a}}$ & $23 / 10 / 2014$ & Violação de direito autoral \\
\hline $\mathbf{8 7}$ & $0039583-61.2009 .8 .26 .0071$ & Luis Soares de Mello & $4^{\mathrm{a}}$ & $09 / 09 / 2014$ & Violação de direito autoral \\
\hline $\mathbf{8 8}$ & $0041052-37.2010 .8 .26 .0224$ & Ricardo Tucunduva & $6^{\mathrm{a}}$ & $11 / 12 / 2014$ & Violação de direito autoral \\
\hline
\end{tabular}




\section{Apêndice E}

\section{Relação dos acórdãos excluídos da pesquisa quantitativa}

\begin{tabular}{|c|c|c|c|c|}
\hline & Acórdão & Relator & Câmara & Julgamento \\
\hline 1 & 0201640-58.2009.8.26.0222 & Ivana David & $4^{\mathrm{a}}$ & $29 / 07 / 2014$ \\
\hline 2 & $0006717-63.2009 .8 .26 .0438$ & Airton Vieira & $1^{\mathrm{a}}$ Extraordinária & $18 / 08 / 2014$ \\
\hline 3 & 0013889-38.2011.8.26.0001 & Paulo Rossi & $12^{\mathrm{a}}$ & $14 / 05 / 2014$ \\
\hline 4 & 0038601-92.2011.8.26.0001 & Paulo Rossi & $12^{\mathrm{a}}$ & $12 / 03 / 2014$ \\
\hline 5 & 0000005-24.2012.8.26.0318 & Lauro Mens de Mello & $8^{\mathrm{a}}$ & $11 / 12 / 2014$ \\
\hline 6 & 0000183-51.2010.8.26.0444 & Lauro Mens de Mello & $8^{\mathrm{a}}$ & $24 / 06 / 2014$ \\
\hline 7 & $0000228-43.2011 .8 .26 .0081$ & Lauro Mens de Mello & $8^{\mathrm{a}}$ & $08 / 05 / 2014$ \\
\hline 8 & $0000287-78.2010 .8 .26 .0400$ & Lauro Mens de Mello & $8^{\mathrm{a}}$ & $05 / 06 / 2014$ \\
\hline 9 & 0000303-53.2010.8.26.0296 & Airton Vieira & $1^{\mathrm{a}}$ Extraordinária & $16 / 06 / 2014$ \\
\hline 10 & 0000336-71.2009.8.26.0104 & Airton Vieira & $1^{\mathrm{a}}$ Extraordinária & $10 / 03 / 2014$ \\
\hline 11 & $0000341-29.2011 .8 .26 .0620$ & Lauro Mens de Mello & $8^{a}$ & $24 / 06 / 2014$ \\
\hline 12 & $0000362-84.2009 .8 .26 .0584$ & Airton Vieira & $1^{\mathrm{a}}$ Extraordinária & $16 / 06 / 2014$ \\
\hline 13 & $0000561-06.2011 .8 .26 .0142$ & Lauro Mens de Mello & $8^{\mathrm{a}}$ & $30 / 03 / 2014$ \\
\hline 14 & 0000791-43.2010.8.26.0058 & Airton Vieira & $1^{\mathrm{a}}$ Extraordinária & $16 / 06 / 2014$ \\
\hline 15 & 0000803-95.2006.8.26.0511 & Airton Vieira & $1^{\mathrm{a}}$ Extraordinária & $10 / 03 / 2014$ \\
\hline 16 & $0001056-30.2006 .8 .26 .0270$ & Airton Vieira & $1^{\mathrm{a}}$ Extraordinária & $21 / 07 / 2014$ \\
\hline 17 & 0001110-44.2011.8.26.0165 & Borges Pereira & $16^{\mathrm{a}}$ & $21 / 01 / 2014$ \\
\hline 18 & 0001111-61.2010.8.26.0198 & Airton Vieira & $1^{\mathrm{a}}$ Extraordinária & $10 / 03 / 2014$ \\
\hline 19 & 0001181-67.2009.8.26.0019 & Airton Vieira & $1^{\mathrm{a}}$ Extraordinária & $17 / 02 / 2014$ \\
\hline 20 & 0001353-44.2009.8.26.0363 & Airton Vieira & $1^{\mathrm{a}}$ Extraordinária & $06 / 10 / 2014$ \\
\hline 21 & 0001360-37.2009.8.26.0201 & Airton Vieira & $1^{\mathrm{a}}$ Extraordinária & $06 / 10 / 2014$ \\
\hline 22 & 0001364-82.2009.8.26.0069 & Lauro Mens de Mello & $8^{\mathrm{a}}$ & $13 / 03 / 2014$ \\
\hline 23 & $0001611-60.2009 .8 .26 .0264$ & Airton Vieira & $1^{\mathrm{a}}$ Extraordinária & $15 / 09 / 2014$ \\
\hline 24 & $0001908-79.2013 .8 .26 .0344$ & Lauro Mens de Mello & $8^{\mathrm{a}}$ & $31 / 07 / 2014$ \\
\hline 25 & $0001961-63.2006 .8 .26 .0584$ & Airton Vieira & $1^{\mathrm{a}}$ Extraordinária & $06 / 10 / 2014$ \\
\hline 26 & $0002243-40.2012 .8 .26 .0213$ & Airton Vieira & $1^{\mathrm{a}}$ Extraordinária & $24 / 11 / 2014$ \\
\hline 27 & $0002281-35.2010 .8 .26 .0306$ & Lauro Mens de Mello & $8^{\mathrm{a}}$ & $06 / 02 / 2014$ \\
\hline 28 & 0002435-09.2011.8.26.0471 & Lauro Mens de Mello & $8^{\mathrm{a}}$ & $30 / 10 / 2014$ \\
\hline 29 & $0002601-75.2005 .8 .26 .0366$ & Airton Vieira & $1^{\mathrm{a}}$ Extraordinária & $21 / 07 / 2014$ \\
\hline 30 & $0002662-77.2007 .8 .26 .0070$ & Airton Vieira & $1^{\mathrm{a}}$ Extraordinária & $15 / 09 / 2014$ \\
\hline 31 & 0002770-95.2010.8.26.0072 & Airton Vieira & $1^{\mathrm{a}}$ Extraordinária & $14 / 04 / 2014$ \\
\hline 32 & 0002872-91.2008.8.26.0459 & Airton Vieira & $1^{\mathrm{a}}$ Extraordinária & 06/10/2014 \\
\hline 33 & $0003009-28.2010 .8 .26 .0128$ & Airton Vieira & $1^{\mathrm{a}}$ Extraordinária & $16 / 06 / 2014$ \\
\hline 34 & $0003462-73.2009 .8 .26 .0252$ & Lauro Mens de Mello & $8^{\mathrm{a}}$ & $24 / 04 / 2014$ \\
\hline 35 & $0003953-60.2012 .8 .26 .0063$ & Airton Vieira & $1^{\mathrm{a}}$ Extraordinária & $24 / 11 / 2014$ \\
\hline 36 & $0004700-72.2009 .8 .26 .0238$ & Airton Vieira & $1^{\mathrm{a}}$ Extraordinária & $06 / 10 / 2014$ \\
\hline 37 & 0004925-42.2010.8.26.0114 & Lauro Mens de Mello & $8^{a}$ & $30 / 01 / 2014$ \\
\hline 38 & $0004984-60.2003 .8 .26 .0539$ & Airton Vieira & $1^{\mathrm{a}}$ Extraordinária & $21 / 07 / 2014$ \\
\hline
\end{tabular}




\begin{tabular}{|c|c|c|c|c|}
\hline 39 & 0005048-84.2010.8.26.0358 & Airton Vieira & $1^{\mathrm{a}}$ Extraordinária & $15 / 09 / 2014$ \\
\hline 40 & $0005483-32.2009 .8 .26 .0572$ & Airton Vieira & $1^{\mathrm{a}}$ Extraordinária & $16 / 06 / 2014$ \\
\hline 41 & 0005673-87.2011.8.26.0066 & Airton Vieira & $1^{\mathrm{a}}$ Extraordinária & $24 / 11 / 2014$ \\
\hline 42 & 0006057-31.2011.8.26.0428 & Airton Vieira & $1^{\mathrm{a}}$ Extraordinária & $14 / 04 / 2014$ \\
\hline 43 & 0006259-25.2011.8.26.0099 & Lauro Mens de Mello & $8^{\mathrm{a}}$ & $14 / 08 / 2014$ \\
\hline 44 & $0006321-21.2010 .8 .26 .0125$ & Airton Vieira & $1^{\mathrm{a}}$ Extraordinária & $10 / 03 / 2014$ \\
\hline 45 & $0006326-53.2010 .8 .26 .0445$ & Lauro Mens de Mello & $8^{\mathrm{a}}$ & $20 / 03 / 2014$ \\
\hline 46 & 0006612-31.2010.8.26.0445 & Lauro Mens de Mello & $8^{a}$ & $08 / 05 / 2014$ \\
\hline 47 & $0006981-66.2012 .8 .26 .0344$ & Airton Vieira & $1^{\mathrm{a}}$ Extraordinária & $24 / 11 / 2014$ \\
\hline 48 & $0006983-36.2012 .8 .26 .0344$ & Lauro Mens de Mello & $8^{\mathrm{a}}$ & $18 / 12 / 2014$ \\
\hline 49 & $0007394-64.2009 .8 .26 .0286$ & Lauro Mens de Mello & $8^{\mathrm{a}}$ & $27 / 02 / 2014$ \\
\hline 50 & 0007414-34.2007.8.26.0445 & Lauro Mens de Mello & $8^{\mathrm{a}}$ & $20 / 03 / 2014$ \\
\hline 51 & 0007829-02.2009.8.26.0201 & Airton Vieira & $1^{\mathrm{a}}$ Extraordinária & $21 / 07 / 2014$ \\
\hline 52 & $0007855-86.2008 .8 .26 .0022$ & Lauro Mens de Mello & $8^{\mathrm{a}}$ & $24 / 06 / 2014$ \\
\hline 53 & 0008922-36.1999.8.26.0270 & Lauro Mens de Mello & $8^{a}$ & $05 / 06 / 2014$ \\
\hline 54 & $0009510-25.2008 .8 .26 .0659$ & Lauro Mens de Mello & $8^{a}$ & $24 / 07 / 2014$ \\
\hline 55 & 0010484-75.2009.8.26.0126 & Airton Vieira & $1^{\mathrm{a}}$ Extraordinária & $19 / 05 / 2014$ \\
\hline 56 & 0010692-04.2011.8.26.0348 & Kenarik Boujikian & $7^{a}$ & $15 / 05 / 2014$ \\
\hline 57 & $0010810-22.2011 .8 .26 .0625$ & Airton Vieira & $1^{\mathrm{a}}$ Extraordinária & $10 / 03 / 2014$ \\
\hline 58 & 0011590-38.2011.8.26.0050 & Lauro Mens de Mello & $8^{\mathrm{a}}$ & 03/04/2014 \\
\hline 59 & 0012400-88.2010.8.26.0198 & Lauro Mens de Mello & $8^{a}$ & $27 / 02 / 2014$ \\
\hline 60 & 0012605-88.2002.8.26.0363 & Airton Vieira & $1^{\mathrm{a}}$ Extraordinária & $19 / 05 / 2014$ \\
\hline 61 & $0013368-14.2011 .8 .26 .0577$ & Airton Vieira & $1^{\mathrm{a}}$ Extraordinária & $06 / 10 / 2014$ \\
\hline 62 & 0015609-98.2008.8.26.0048 & Lauro Mens de Mello & $8^{\mathrm{a}}$ & $11 / 06 / 2014$ \\
\hline 63 & 0016072-54.2010.8.26.0344 & Lauro Mens de Mello & $8^{\mathrm{a}}$ & $24 / 06 / 2014$ \\
\hline 64 & 0017649-33.2011.8.26.0344 & Lauro Mens de Mello & $8^{\mathrm{a}}$ & $24 / 06 / 2014$ \\
\hline 65 & 0018664-60.2010.8.26.0477 & Lauro Mens de Mello & $8^{a}$ & $05 / 06 / 2014$ \\
\hline 66 & 0018890-98.2011.8.26.0196 & Lauro Mens de Mello & $8^{\mathrm{a}}$ & $11 / 06 / 2014$ \\
\hline 67 & 0022921-50.2009.8.26.0482 & Lauro Mens de Mello & $8^{a}$ & $24 / 07 / 2014$ \\
\hline 68 & 0031721-88.2012.8.26.0344 & Francisco Bruno & $10^{\mathrm{a}}$ & $14 / 07 / 2014$ \\
\hline 69 & 0039821-34.2012.8.26.0602 & Airton Vieira & $1^{\mathrm{a}}$ Extraordinária & $24 / 11 / 2014$ \\
\hline 70 & 0057100-74.2011.8.26.0050 & Lauro Mens de Mello & $8^{\mathrm{a}}$ & $05 / 06 / 2014$ \\
\hline 71 & $0059050-26.2010 .8 .26 .0577$ & Lauro Mens de Mello & $8^{\mathrm{a}}$ & $22 / 05 / 2014$ \\
\hline 72 & 0061186-20.2013.8.26.0050 & Airton Vieira & $1^{\mathrm{a}}$ Extraordinária & $15 / 12 / 2014$ \\
\hline 73 & $0064931-47.2009 .8 .26 .0050$ & Airton Vieira & $1^{\mathrm{a}}$ Extraordinária & $14 / 04 / 2014$ \\
\hline 74 & $0082667-44.2010 .8 .26 .0050$ & Airton Vieira & $1^{\mathrm{a}}$ Extraordinária & $18 / 08 / 2014$ \\
\hline 75 & $0083662-86.2012 .8 .26 .0050$ & Lauro Mens de Mello & $8^{\mathrm{a}}$ & 04/09/2014 \\
\hline 76 & 0090135-88.2012.8.26.0050 & Lauro Mens de Mello & $8^{a}$ & $24 / 07 / 2014$ \\
\hline 77 & 0102044-98.2010.8.26.0050 & Airton Vieira & $1^{a}$ Extraordinária & $18 / 08 / 2014$ \\
\hline 78 & 0102881-56.2010.8.26.0050 & Lauro Mens de Mello & $8^{\mathrm{a}}$ & $06 / 02 / 2014$ \\
\hline 79 & $0776945-90.2009 .8 .26 .0577$ & Airton Vieira & $1^{\mathrm{a}}$ Extraordinária & $14 / 04 / 2014$ \\
\hline 80 & $9000103-15.2011 .8 .26 .0050$ & Lauro Mens de Mello & $8^{\mathrm{a}}$ & $11 / 12 / 2014$ \\
\hline 81 & $9000157-44.2006 .8 .26 .0506$ & Lauro Mens de Mello & $8^{\mathrm{a}}$ & $06 / 02 / 2014$ \\
\hline 82 & $0000154-12.2012 .8 .26 .0062$ & Encinas Manfré & $15^{\mathrm{a}}$ & $06 / 11 / 2014$ \\
\hline 83 & 0000593-74.2012.8.26.0627 & Francisco Bruno & $10^{\mathrm{a}}$ & $25 / 09 / 2014$ \\
\hline
\end{tabular}




\begin{tabular}{|l|c|c|c|c|}
$\mathbf{8 4}$ & $0000774-93.2010 .8 .26 .0191$ & Juvenal Duarte & $5^{\mathrm{a}}$ & $24 / 04 / 2014$ \\
\hline $\mathbf{8 5}$ & $0001081-35.2008 .8 .26 .0153$ & Nelson Fonseca Júnior & $1^{\text {a }}$ Extraordinária & $24 / 11 / 2014$ \\
\hline $\mathbf{8 6}$ & $0001099-91.2011 .8 .26 .0269$ & Nelson Fonseca Júnior & $15^{\mathrm{a}}$ & $05 / 06 / 2014$ \\
\hline $\mathbf{8 7}$ & $0001153-41.2012 .8 .26 .0069$ & Luiz Antonio Cardoso & $3^{\mathrm{a}}$ & $29 / 07 / 2014$ \\
\hline $\mathbf{8 8}$ & $0003287-04.2009 .8 .26 .0083$ & Zorzi Rocha & $3^{\mathrm{a}}$ Extraordinária & $10 / 04 / 2014$ \\
\hline $\mathbf{8 9}$ & $0003339-70.2005 .8 .26 .0299$ & Roberto Solimene & $9^{\mathrm{a}}$ & $09 / 10 / 2014$ \\
\hline $\mathbf{9 0}$ & $0003564-57.2011 .8 .26 .0048$ & Camilo Léllis & $8^{\mathrm{a}}$ & $27 / 02 / 2014$ \\
\hline $\mathbf{9 1}$ & $0009007-46.2013 .8 .26 .0071$ & Souza Nery & $9^{\mathrm{a}}$ & $16 / 10 / 2014$ \\
\hline $\mathbf{9 2}$ & $0013406-37.2010 .8 .26 .0132$ & Edison Brandão & $4^{\mathrm{a}}$ & $04 / 02 / 2014$ \\
\hline $\mathbf{9 3}$ & $0019644-53.2011 .8 .26 .0224$ & Walter da Silva & $14^{\mathrm{a}}$ & $26 / 06 / 2014$ \\
\hline $\mathbf{9 4}$ & $0028901-89.2011 .8 .26 .0196$ & Alex Zilenovski & $2^{\mathrm{a}}$ & $29 / 09 / 2014$ \\
\hline $\mathbf{9 5}$ & $0052058-07.2011 .8 .26 .0515$ & Roberto Solimene & $9^{\mathrm{a}}$ & $13 / 11 / 2014$ \\
\hline $\mathbf{9 6}$ & $0052412-32.2011 .8 .26 .0515$ & Souza Nery & $9^{\mathrm{a}}$ & $30 / 10 / 2014$ \\
\hline
\end{tabular}

